\title{
Hydrothermal Alteration and Its Superimposed Enrichment for Qianjiadian Tabular-Type Uranium Deposit in Southwestern Songliao Basin
}

\author{
Ming-Kuan Qin ${ }^{1}{ }^{*}$, Shao-Hua Huang ${ }^{1, *}$, Jia-Lin Liu ${ }^{1}$, Zhang-Yue Liu ${ }^{1}$, Qiang Guo ${ }^{1}$, Li-Cheng Jia ${ }^{1}$ \\ and Wen-Jian Jiang ${ }^{2}$
}

1 CNNC Key Laboratory of Uranium Resource Exploration and Evaluation Technology, Beijing Research Institute of Uranium Geology, Beijing 100029, China; liujialin@briug.cn (J.-L.L.);

liuzhangyue@briug.cn (Z.-Y.L.); guoqiang@briug.cn (Q.G.); jialicheng@briug.cn (L.-C.J.)

2 State Key Laboratory of Nuclear Resource and Environment, East China Institute of Technology, Nanchang 330013, China; jiang2017@ecut.edu.cn

* Correspondence: qinmingkuan@briug.cn (M.-K.Q.); huangshaohua@briug.cn (S.-H.H.); Tel.: +86-010-6491-2382 (S.-H.H.)

Citation: Qin, M.-K.; Huang, S.-H.; Liu, J.-L.; Liu, Z.-Y.; Guo, Q.; Jia, L.-C.; Jiang, W.-J. Hydrothermal Alteration and Its Superimposed Enrichment for Qianjiadian Tabular-Type Uranium Deposit in Southwestern Songliao Basin. Minerals 2022, 12, 52. https:// doi.org/10.3390/min12010052

Academic Editor: David Quirt

Received: 25 November 2021

Accepted: 28 December 2021

Published: 30 December 2021

Publisher's Note: MDPI stays neutral with regard to jurisdictional claims in published maps and institutional affiliations.

Copyright: (C) 2021 by the authors. Licensee MDPI, Basel, Switzerland. This article is an open access article distributed under the terms and conditions of the Creative Commons Attribution (CC BY) license (https:// creativecommons.org/licenses/by/ $4.0 /)$.

\begin{abstract}
The evolution characteristics of hydrothermal activity and superimposed uranium mineralization in the Qianjiadian ore field in southwestern Songliao Basin are still controversial and lack direct evidence. In this comprehensive study, a detailed identification of dolerite and hydrothermally altered un-mineralized sandstone and sandstone-hosted ore in the Yaojia Formation have been performed through the use of scanning electron microscopy observation, electron probe, carbonoxygen-sulfur isotope, and fluid inclusion analyses. The results show that the hydrothermal fluid derived from the intermediate-basic magma intrusion is a low-temperature reducing alkaline fluid and rich in $\mathrm{CO}_{2}, \mathrm{Si}, \mathrm{Zr}, \mathrm{Ti}, \mathrm{Fe}, \mathrm{Mg}, \mathrm{Mn}$, and $\mathrm{Ca}$, producing different types of altered mineral assemblages in the rocks, including carbonation, pyritization, sphalerite mineralization, clausthalite mineralization, silicification, and biotitization. Specifically, the carbonate minerals in sandstone are mixed products of deep hydrothermal fluid and meteoric water, with carbon and oxygen isotopes ranging from $-5.2 \%$ to $-1.7 \%$ and $-20.4 \%$ o to $-11.1 \%$, respectively. Carbon source of the carbonate minerals in dolerite is mainly inorganic carbon produced at the late stage of intermediatebasic magma evolution, with carbon and oxygen isotopes from $-16.1 \%$ o to $-7.2 \%$ and $-18.2 \%$ o to $-14.5 \%$, respectively. Various carbonate minerals in the rocks may have been precipitated by the hydrothermal fluid after the magmatic stage, due to the change of its $\mathrm{CO}_{2}$ fugacity, temperature, and cation concentration during the long-term evolution stage. A series of carbonate minerals were generated as calcite, dolomite, ankerite, ferromanganese dolomite, and dawsonite. The precipitation processes and different types of carbonate mineral mixtures identified in this study mainly occur as parallel, gradual transition, interlacing, or inclusion metasomatism in the same vein body, without obvious mineralogical and petrologic characteristics of penetrating relationship. Homogenization temperature of fluid inclusions in calcite is high, in the range of $203-234{ }^{\circ} \mathrm{C}$, with a low salinity of $0.71-4.34 \% \mathrm{NaCl}$, and the data range is relatively concentrated. Homogenization temperature of fluid inclusions in ankerite is usually low, ranging from $100{ }^{\circ} \mathrm{C}$ to $232{ }^{\circ} \mathrm{C}$, with a high salinity of $4.18-9.98 \% \mathrm{NaCl}$. The precipitation processes of carbonate minerals and the results of this study are basically in consistent. Overall, the sandstone-type uranium deposits have a temporal and genetic relationship with hydrothermal activities during Paleogene. (1) Hydrothermal activity was directly involved in uranium mineralization, result in dissolution and reprecipitation of earlier uranium minerals, forming uranium-bearing ankerite and complexes containing uranium, zirconium, silicon, and titanium. (2) Hydrothermal fluid activity provided reducing agent to promote hydrocarbon generation from pyrolysis of carbonaceous fragments and accelerate uranium precipitation rate. (3) Regional water stagnation prolongs reaction time, contributing to huge uranium enrichment. This study provides new petrologic, mineralogical, and geochemical evidence for multi-fluid coupled and superimposed mineralization of sandstone-hosted uranium deposits in the sedimentary basin.
\end{abstract}


Keywords: hydrothermal fluid; altered minerals; stable isotopes; fluid inclusions; Yaojia Formation and dolerite; sandstone-hosted uranium deposit; Songliao Basin

\section{Introduction}

All kinds of fluid activities in sedimentary basins are the main driving force and material source for the formation and distribution of various energy mineral resources [1,2]. They play an important role in controlling the formation and orientation of oil and gas reservoirs (generation, reservoir, migration, and sealing) [3], Mississippi-type Pb-Zn ore [4], Carlin-type gold deposit [5], sedimentary-type uranium [6], iron, and copper deposits, etc. Classic metallogenic theory of hydrogenic uranium deposits proposes that sandstonetype uranium deposit is mineralized through oxidation-reduction of pyrite and carbon fragment as shallow cryogenic, oxic, and uranium-rich groundwater seeping into the target segments in the basin edge [7]. This process is mainly controlled by several critical factors including the uranium source, structure, paleoclimate, lithology and lithofacies, hydrogeology, epigenetic oxidation alteration, etc. [8]. In addition, escape of hydrocarbon fluid in deep petroliferous basins also has a significant influence on the formation and preservation of uranium deposits [9]. In recent years, increasing evidence has accumulated, showing that deep-source thermal fluids in the sedimentary basins play an obvious role in the superimposed alteration of ore bodies or directly involved in uranium mineralization [10,11]. Worldwide uranium deposits have characteristics of deep thermal fluid alteration at varying degrees [12], such as Azelik deposit in Niger [13], Savabuqi deposit in northwestern margin of the Tarim Basin [14], Dongsheng deposit in northwestern margin of the Ordos Basin [15,16], Tamusu deposit in Bayon gobi Basin [17,18], Qianjiadian deposit in the Songliao Basin [8,19]. This brings new challenges and opportunities for innovation in breakage of the traditional low temperature metallogenic theory of sandstone-type uranium deposit [20], which will contribute to guide the prospection and exploration of ore deposits.

The tectono-magmatic activities in southwest Songliao Basin during Meso-Cenozoic were intense and complex [21], developing multiple episodes of intermediate-basic igneous rocks such as dolerite and basalt [22]. Dolerite intrusion has been found in many sandstonetype uranium deposits in the study area $[23,24]$, with distinct metallogenic characteristics from those of sandstone-type uranium deposits characterized by typical interlayer redox genesis zone in Yili and the Turpan-Hami Basins [25]. Previous studies have shown that all ore bodies in Qianjiadian ore field are tabular, lamellar, and lenticular, with the genetic characteristics of "double open mineralization system" of infiltration and exudation type [26]. The sandstone-hosted ore of Yaojia Formation has obvious hydrothermal superimposed mineralization in the later period [27]. The metallogenic environment has changed from faintly acidic to weakly alkaline conditions, with low-temperature hydrothermal alteration of mineral assemblages generally developed, such as ferro-dolomitization, pyritization, hydromicazation, and sericitization [28,29]. However, systematic research on geochemical properties, evolution features, and xenogenous alteration characteristics of deep-source thermal fluids is still limited at present. Absence of direct evidence of hydrothermal mineralization brings about divergent understandings of the relationship between thermal events and uranium mineralization, resulting in the existence of diverse views. For instance, different understandings exist on the stages of hydrothermal activities including one episode [30], two episodes, and three episodes [31]. Moreover, comparative studies on hydrothermal veins in dolerite are still limited. Consequently, hand specimen observation, thin section identification, scanning electron microscopy, electron probe, carbon-oxygensulfur isotope analysis, and fluid inclusion analysis have been carried out on dolerite and hydrothermally altered barren sandstone and sandstone-hosted ore of Qianjiadian deposit in southwestern Songliao Basin, aiming to comprehensively describe the petrologic, mineralogical, and geochemical characteristics of deep hydrothermal fluid activities in the study area. This study provides, for the first time, the petrologic and geochemical 
evidence of hydrothermally superimposed mineralization, based on achievements of previous researchers and the latest actual exploration data. An in-depth discussion also covers the evolution process of hydrothermal fluids and metallogenic effect of sandstone-type uranium mineralization in the study area. The research results not only further deepen and improve the metallogenic mechanism of multi-fluid superpimposition of sandstone-type uranium deposits in the basin, but also provide new clues and ideas for the location and exploration of deep uranium deposits in the Songliao Basin and even in the Mesozoic and Cenozoic basins in northern China. The results have important theoretical value and practical guiding significance.

\section{Geological Setting}

\subsection{The Songliao Basin}

The Songliao Basin, rich in various energy mineral resources of oil and gas, coal, uranium, etc., is an inland superimposed basin converted from rift depression in eastern China during the middle and late Mesozoic and Cenozoic [3,32]. It is located between $119^{\circ} 40^{\prime} \mathrm{E}$ and $128^{\circ} 24^{\prime} \mathrm{E}$ in longitude and $42^{\circ} 25^{\prime} \mathrm{N}$ and $49^{\circ} 23^{\prime} \mathrm{N}$ in latitude (Figure 1a), with an orientation of NNE, $750 \mathrm{~km}$ in length and 330-370 km in width, and a total area of $260,000 \mathrm{~km}^{2}[29,30]$. The basin can be tectonically divided into seven first-order tectonic units (Figure 1b), i.e., the Central depression, Northeastern uplift, Southeastern uplift, Southwestern uplift, Western slope, Northern pitching area, and Kailu depression [24,33]. Among them, the Qianjiadian (QJD) ore field is located in the transition between Kailu depression and Southwestern uplift area [34].

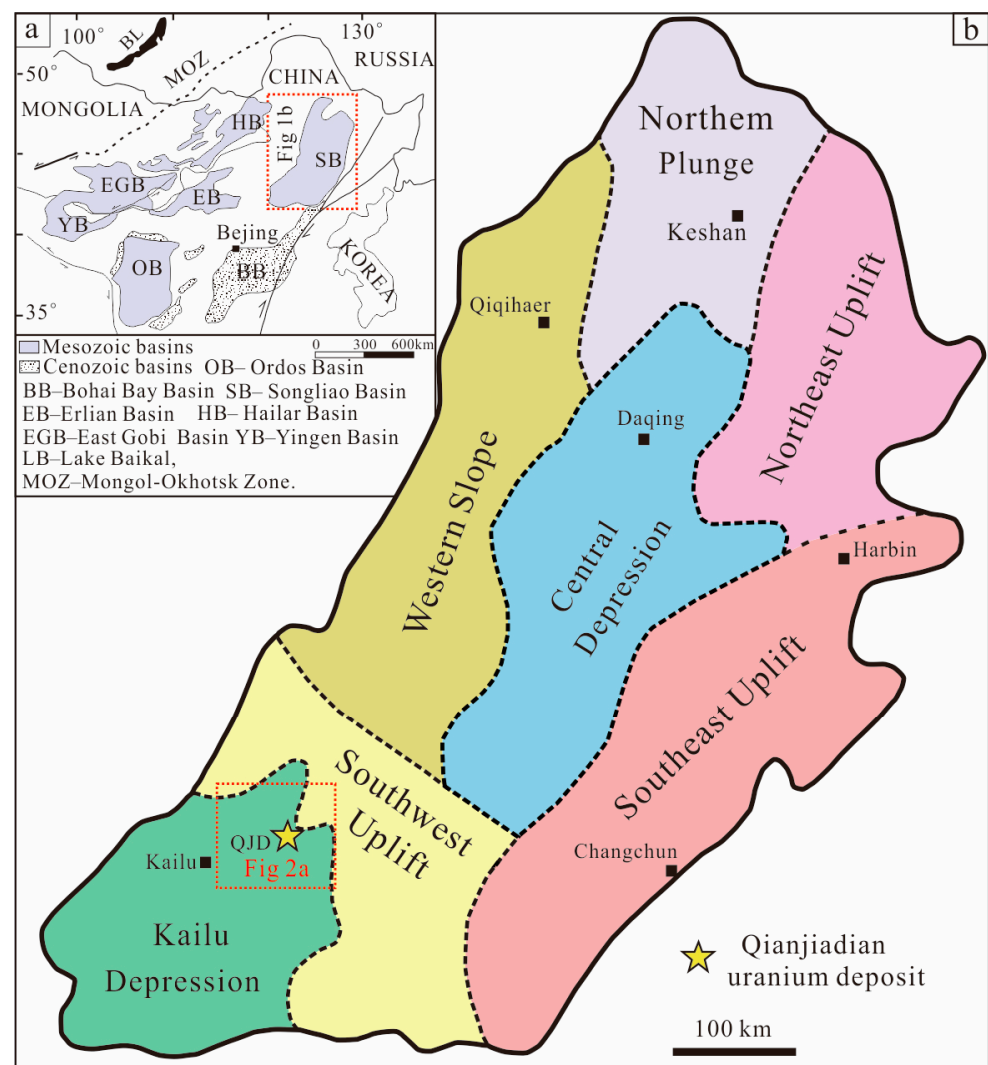

\begin{tabular}{|c|c|c|c|c|c|}
\hline \multicolumn{2}{|c|}{ c. ${ }_{\text {Stratigraphic unit }}$} & $\begin{array}{c}\text { Thickness } \\
(\mathrm{m})\end{array}$ & $\begin{array}{l}\text { Sequence } \\
\text { Bar Chart }\end{array}$ & $\begin{array}{l}\text { Sedimentary } \\
\text { environment }\end{array}$ & $\begin{array}{c}\text { Tectonic } \\
\text { stage }\end{array}$ \\
\hline \multicolumn{2}{|c|}{ Quaternary } & $0 \sim 140$ & & \multirow{4}{*}{$\begin{array}{c}\text { Alluvial fan } \\
\text { fluvial flood } \\
\text { plain }\end{array}$} & \multirow{6}{*}{ 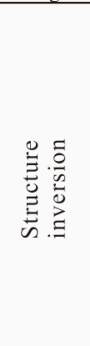 } \\
\hline \multirow{2}{*}{ 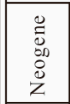 } & 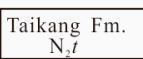 & $0 \sim 134$ & & & \\
\hline & $\begin{array}{l}\mathrm{Da} \text { 'an } \mathrm{Fm} . \\
\mathrm{N}_{1} d\end{array}$ & $0 \sim 98$ & $\therefore$ & & \\
\hline \begin{tabular}{|l|}
$\begin{array}{l}\text { Paleo- } \\
\text { gene }\end{array}$ \\
\end{tabular} & $\underset{E_{1-2} y}{\text { Yian }} \mathrm{Fm}$. & $0 \sim 260$ & & & \\
\hline \multirow{6}{*}{ 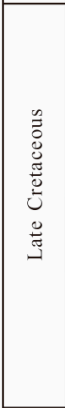 } & $\underset{\mathrm{K}_{2} m}{\operatorname{Mingshui} \mathrm{Fm} .}$ & $0 \sim 281$ & & \multirow{2}{*}{$\begin{array}{l}\text { Meandering } \\
\text { river delta, } \\
\text { shallow lake }\end{array}$} & \\
\hline & $\begin{array}{c}\text { Sifangtai Fm. } \\
\mathrm{K}_{2} s\end{array}$ & $0 \sim 413$ & & & \\
\hline & $\underset{\substack{\text { Nenjiang } \\
\mathbf{K}_{2} n}}{\mathrm{Fm} .}$ & $138 \sim 1162$ & & $\begin{array}{l}\text { Shallow lake, } \\
\text { deep-shallow lake, } \\
\text { large deep lake }\end{array}$ & \multirow{4}{*}{$\begin{array}{l}= \\
\vdots \\
0 \\
0 \\
0\end{array}$} \\
\hline & $\begin{array}{c}\text { Yaojia Fm. } \\
\mathrm{K}_{2} y\end{array}$ & $60 \sim 228$ & $\because$ & $\begin{array}{l}\text { Braided river, } \\
\text { shallow lake, } \\
\text { exposure }\end{array}$ & \\
\hline & $\begin{array}{l}\text { Qingshank- } \\
\text { ou FM. } \\
\mathrm{K}_{2} q n\end{array}$ & $360 \sim 716$ & $\begin{array}{l}\because-8 \\
-- \\
-9 \\
-9\end{array}$ & $\begin{array}{l}\text { Delta,deep- } \\
\text { shallow lake, } \\
\text { deep lake }\end{array}$ & \\
\hline & $\begin{array}{c}\text { Quantou Fm. } \\
\mathrm{K}_{2} q\end{array}$ & $0 \sim 1858$ & & $\begin{array}{c}\begin{array}{c}\text { Meandering river } \\
\text { delta, } \\
\text { shallow lake }\end{array} \\
\end{array}$ & \\
\hline \multirow{3}{*}{ 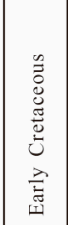 } & $\begin{array}{c}\text { Denglouke Fm } \\
\mathrm{K}_{1} d\end{array}$ & $0 \sim 2339$ & $\because \because$ & $\begin{array}{c}\text { Braided river, } \\
\text { delta, } \\
\text { large lake }\end{array}$ & \multirow{3}{*}{ 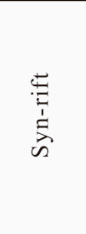 } \\
\hline & $\begin{array}{c}\text { Yingcheng Fm } \\
\mathrm{K}_{1} y c\end{array}$ & $0 \sim 847$ & & $\begin{array}{c}\text { Fan delta, } \\
\text { delta, } \\
\text { deep lake }\end{array}$ & \\
\hline & $\begin{array}{c}\text { Shahezi Fm. } \\
\mathrm{K}_{1} \text { sh }\end{array}$ & $0 \sim 903$ & $\begin{array}{l}\overline{-} \\
\overline{-} \\
- \\
\end{array}$ & $\begin{array}{l}\text { Alluvial fan, delta, } \\
\text { deep lake }\end{array}$ & \\
\hline 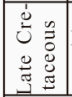 & $\begin{array}{c}\text { Huoshiling Fm } \\
\mathbf{J}_{3}\end{array}$ & $0 \sim 1600$ & & $\begin{array}{l}\text { Alluvial,shallow } \\
\text { lake,volcanic roks }\end{array}$ & Pre-rift \\
\hline
\end{tabular}

Figure 1. Location (a), Tectonic units (b) and Stratigraphic column (c) of the Songliao Basin (a modified from [33]; b modified from [24]).

The basin has three stages of tectonic evolution including rifting, depression, and depression shrinkage (Figure 1c) [35], which are further divided into six stages [36]: (1) evolution stage of craton basement in early Mesozoic, (2) stage of rifting development in 
the Huoshiling-Denglouku period $\left(\mathrm{J}_{3} h-\mathrm{K}_{1} d\right)$ in Late Jurassic-Early Cretaceous, (3) thermal depression stage in the Quantou-Nenjiang period $\left(\mathrm{K}_{2} q-\mathrm{K}_{2} n\right)$ in Late Cretaceous, (4) stage of extrusion, tilt, and shrinkage, with local uplift and erosion in the Sifangtai-Mingshui $\left(\mathrm{K}_{2} s-\mathrm{K}_{2} m\right)$ in Late Cretaceous, (5) stage of overall uplift and erosion in Paleocene-Eocene $\left(E_{1}-E_{2}\right)$, and (6) differential uplift stage in Oligocene-Quaternary $\left(E_{3}-Q\right)$.

The basement of the basin is mainly composed of pre-Sinian hypometamorphic crystalline basement (including these lithologies of granite gneiss, sericite-chlorite gneiss, metasandstone, metamudstone, and quartz gneiss, etc.), Paleozoic fold basement (mainly composed of slate, crystalline limestone, phyllite, etc.), and granite in each period [25]. The sedimentary cover consists of the Mesozoic and Cenozoic sedimentary rock series (Figure 1c), including Shahezi, Yingcheng, and Denglouku Formations of Lower Cretaceous, Quantou, Qingshankou, Yaojia, Nenjiang, Sifangtai and Mingshui Formations of Upper Cretaceous, Yi 'an Formation of Paleogene, Da 'an and Taikang Formations of Neogene and Quaternary [31,37]. The basin had the maximum flooding period during the Nenjiang period (from approximately $84 \mathrm{Ma}$ to approximately $73 \mathrm{Ma}$ ), with lacustrine mudstone widely overlapped with the Yaojia Formation and its underlying caprock [38]. Yaojia Formation (developed from approximately $88.5 \mathrm{Ma}$ to approximately $84 \mathrm{Ma}$ ), as the main mining horizon (Figure 1c), is composed of red and variegated fluvial and lacustrine deposits formed under arid and semi-arid paleo-climate conditions [39].

\subsection{The QJD Uranium Ore Field}

The study area is dominantly distributed in the north of Qianjiadian rift depression [25], including uranium deposits of Qian II, Qian III, Qian IV, Qian V, and Baolongshan, circling around the surrounding layer of the denudation skylight of Baixingtu structure (Figure 2a) [32,38]. According to the latest exploration results, sandstone-type uranium mineralization is principally controlled by braided channel, gray layer, and regional interlayer oxidation zone, with a unified regional metallogenic background and ore-controlling factors [36]. The main mining horizon in the mine lot is the fluvial deposits of the lower member of Yaojia Formation (Figure 2b). Stratigraphic structure of mud-sand-mud in the mine is relatively stable [37]. Sand body of a single-layer channel is generally $20-50 \mathrm{~m}$ and the total thickness is in the range of 100-320 m, with good stability and connectivity [28]. The depth and thickness of the stratum gradually deepen and thicken from the northeast to the southwest.

In the section, all ore bodies in the mining horizon are tabular and lamellar and only a few is lenticular and nest-like (Figure 2b), with their dip and strike consistent with the attitude of the stratum [35]. Ore is not developed in the head and wing parts. Specifically, multiple layers of orebodies are produced in the transition between red oxidation zone and gray layer, with an average grade of about $0.0265 \% / \mathrm{U}$, a thickness of $4-10 \mathrm{~m}$, uranium content of $2-8 \mathrm{~kg} / \mathrm{m}^{2}$, and a burial depth of 254-740 $\mathrm{m}$ [36]. They have the same characteristics of a gradually increasing trend from NE to SW as those of stratum and the xenogenous oxidation zone. Lithology of the host rocks of ore deposits is dominantly gray and grayish white medium-fine sandstone and secondly gray and grayish white coarse sandstone and sandy conglomerate, with a few of gray mudstone [38]. The sandstone ore has a moderate-poor sorting and sub-angular roundness, with low compositional and structural maturity. Mud cement is generally loose and has good permeability, with a few calcium cement compacted [29]. A small amount of black carbon fragments and stellate pyrite can be observed with naked eyes in the ore, indicating that they have a certain of primary reduction capacity [36]. Reduction alteration of episodic exudation of hydrocarbon fluids was existed in the deep in Lower Cretaceous [3]. Previous studies have captured metallogenic ages of $40 \pm 3 \mathrm{Ma}, 53 \pm 3 \mathrm{Ma}, 67 \pm 5 \mathrm{Ma}$, and $96 \pm 14 \mathrm{Ma}$ for ore deposits in Qianjiadian-Baolongshan through $\mathrm{U}-\mathrm{Pb}$ isotopic analysis of the bulk ores and single mineral [40], indicating that uranium mineralization in the area has a characteristic of multi-stage mineralization. 


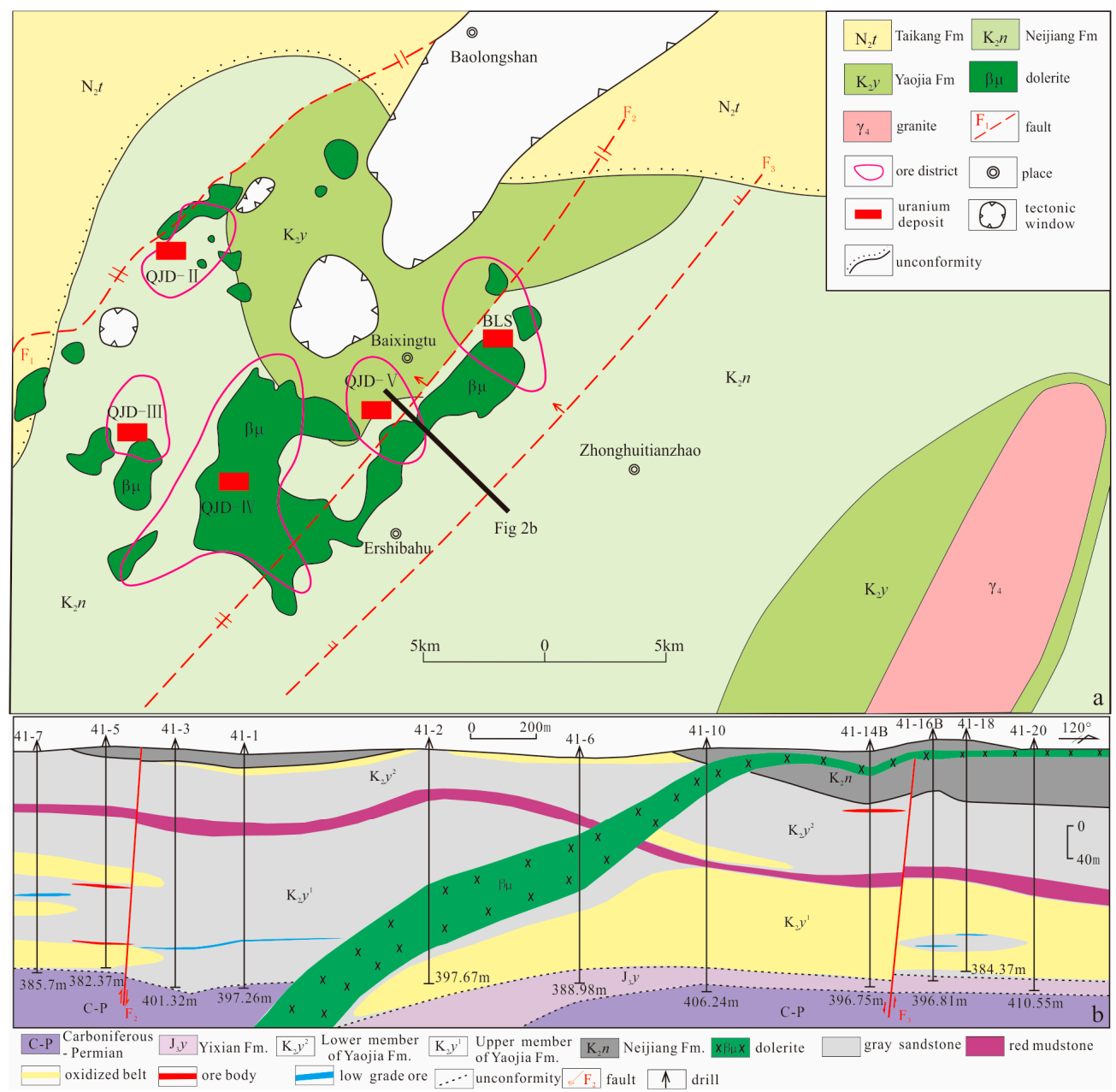

Figure 2. Plane (a) and profile (b) distribution of uranium deposits and dolerite in Qianjiadian ore field (a modified from [35]).

Additionally, the deep basic magmatic activities are under controlled by the intersection of nearly EW-trending faults and NE-trending faults [24], which were cutting through the basement (Figure 2a). Distribution of dolerite overlaps with the development position of orebody in the plane [30]. In the borehole section, some dolerite can be observed penetrated in the Qingshankou and Yaojia Formations with a vein shape (Figure 2b), and finally pitched out in the Nenjiang Formation with lamellar and pillow shapes [31], indicating that the deep fluid activity may have an important superimposition alteration on sandstone-type uranium mineralization in the Qianjiadian ore field.

\section{Sample Collection and Analysis}

In this study, about 26 samples collected from several boreholes in different parts of the Qianjiadian ore field were used to identify the petrologic, mineralogical, and geochemical framework generated during hydrothermal events in the study area and their impact on uranium mineralization. Lithology of the samples includes dolerite containing carbonate vein and interspersed within the Yaojia Formation, as well as gray tight barren sandstone and sandstone-hosted ore with obvious hydrothermal alteration at the macro level in the Yaojia Formation. All the samples were observed, photographed, and described in detail in the field. Firstly, the optical and inclusion thin sections were made in the laboratory. Then the microscopic mineragraphy was studied using polarizing microscope, scanning electron microscope, and with energy dispersive spectrometer. The high resolution field emission scanning electron microscope of Nova Nano SEM450 (Thermo Fisher Scientific, Waltham, 
MA, USA) has an acceleration voltage of $20 \mathrm{kV}$, a working distance of $10 \mathrm{~mm}$, and secondary electron (SE) imaging resolution under low vacuum, $1.5 \mathrm{~nm}, 30 \mathrm{kV}$ and under high vacuum, $1.0 \mathrm{~nm}$, and $15 \mathrm{kV}$. The backscattering condition of $30 \mathrm{kV}$ is better than that of $1.5 \mathrm{~nm}$, while the backscattering condition of $10 \mathrm{kV}$ is better than that of $3.5 \mathrm{~nm}$. The magnification ranges in 20-1,000,000 times. The OXFORD X-MAX80 (OXFORD INSTRUMENTS, Abindon, UK) model of spectrometer has the pulse processor set at $275 \mathrm{kcps}$, the input counting rate between 300 and $450 \mathrm{cps}$, and the analytical elements of Be-U. Finally, some representative samples were selected for carbon-oxygen-surfer isotopic analyses at different scales, fluid inclusion analysis, and electron probe analysis. Detailed processes and analytical methods are as follows.

\subsection{Electron Microprobe Analysis}

Scanning electron microscopy (SEM) and electron microprobe analysis (EPMA) were performed on four samples of gray tight altered sandstone from Yaojia Formation, in order to measure the type and composition of carbonate cements (Table 1). One of the four samples was used to conduct uranium mineral identification and quantitative analysis of its composition through electron microprobe analysis. The JXA-8100 model (JEOL, Tokyo, Japan) of the electron microprobe was used in this study. The acceleration voltage and beam current were $20 \mathrm{kV}$ and $10 \mathrm{nA}$, respectively The beam spot diameter was $2-5 \mu \mathrm{m}$, and counting times were 10-15 s. The spectral quantitative analysis and calibration method was used with the Structure Probe, Inc. 53 (SPI 53)minerals standard (West Chester, PA, USA) and the ZAF ( $\mathrm{Z}=$ Atomic number correction factor, $\mathrm{A}=$ Absorption correction factor, $\mathrm{F}=$ Fluorescence correction factor) correction, respectively. The EMPA-analyzed results and stoichiometrically calculated mineral formulas are presented in [41]. Therein, the $\mathrm{CO}_{2}$ content is equivalently calculated according to the total number of cations.

\subsection{Carbon and Oxygen Isotope Analyses}

Firstly, carbon and oxygen isotopic analyses were performed on the bulk rock carbonate cements of eight tight sandstones at 200 meshes (Table 2). Then, single carbonate mineral was selected from the 4 tight sandstones and 7 dolerite samples under microscope observation, before crushed to 200 mesh using ceramic grinding, in preparation for carbon and oxygen isotopic analyses of single mineral. Among them, ankerite and dawsonite are mixed up and unable to be separated, and thus unified into one sample. The $\delta^{13} \mathrm{C}$ and $\delta^{18} \mathrm{O}$ isotopic compositions were determined using anhydrous phosphoric acid method. Approximately 2 to $5 \mathrm{mg}$ of powdered samples were placed in an oven at $105^{\circ} \mathrm{C}$ for $2 \mathrm{~h}$ to remove adsorbed water. Then, the samples were reacted with $100 \%$ phosphoric acid at $25^{\circ} \mathrm{C}$ for $4 \mathrm{~h}$ to extract $\mathrm{CO}_{2}$ gas in the carbonate cement. The released $\mathrm{CO}_{2}$ gas was carried into MAT-253 (Thermo Fisher Scientific, Waltham, MA, USA) gas isotope mass spectrometer with highly pure helium gas to analyze the ${ }^{13} \mathrm{C} /{ }^{12} \mathrm{C}$ ratio. The analysis accuracy was typically better than $\pm 0.2 \%$. Carbon and oxygen isotope compositions were given relative to the international PDB (Pee Dee Belemnite) standards. The empirical relationship $\left(\delta^{18} \mathrm{O}_{\mathrm{SMOW}}=1.03086^{*} \delta^{18} \mathrm{O}_{\mathrm{PDB}}+30.86\right)$ reported from Friedman and $\mathrm{O}^{\prime}$ Neil (1977) [18] was used for the conversion between the PDB and the SMOW standard.

\subsection{Sulfur Isotopic Analysis}

Sulfur isotopic composition of three sandstone bulk-rock samples were measured using the dissolution method (Table 3). Two samples of pyrite grains were manually selected under microscope observation and crushed into 200 meshes, before performing sulfur isotopic analysis of single mineral using the dissolution method. The samples were analyzed using gas isotope mass spectrometry and formularized in Delta V Plus (Thermo Fisher Scientific, Waltham, MA, USA) after dissolved with oxygen at $1030{ }^{\circ} \mathrm{C}$. Standardization was based on international standards OGS-1 and NBS123. The precision was estimated to be $\pm 0.2 \%$ or better. 
Table 1. EPMA data of carbonate minerals and pitchblende of the altered sandstone in the lower member of Yaojia Formation.

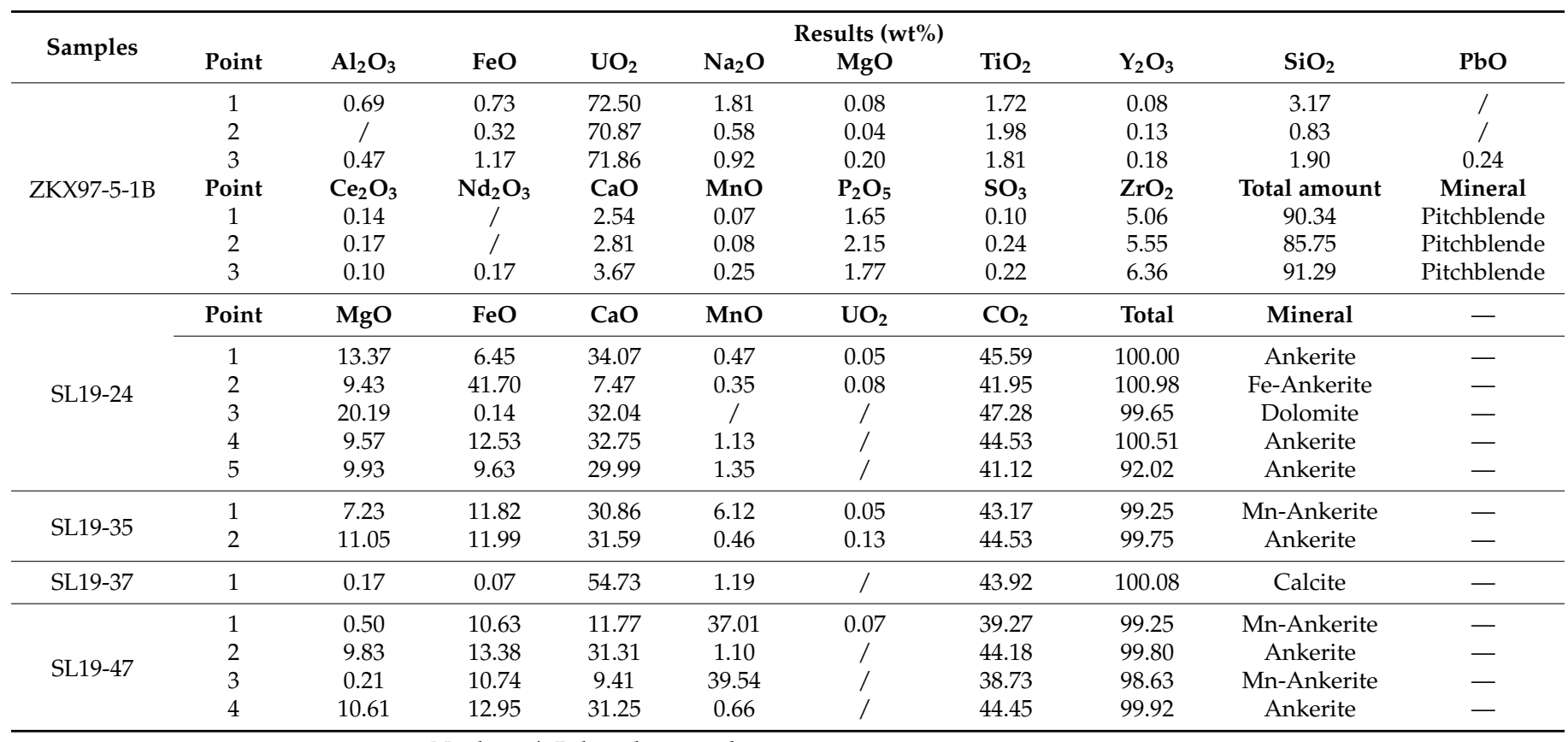

—: No data, /: Below detection limit.

Table 2. $\mathrm{C}$ and $\mathrm{O}$ isotopic compositions of carbonate from dolerite and altered sandstone in the Lower member of Yaojia Formation.

\begin{tabular}{ccccc}
\hline Samples & $\begin{array}{c}\text { Lithology and } \\
\text { Stratigraphy }\end{array}$ & $\mathcal{\delta}^{\mathbf{1 3}} \mathbf{C}_{\mathbf{P D B}}$ & $\mathcal{\delta}^{\mathbf{1 8}} \mathbf{O}_{\mathbf{P D B}}$ & $\mathcal{\delta}^{\mathbf{1 8}} \mathbf{O}_{\mathbf{P D B}}$ \\
\hline SL19-2 & & -0.5 & -17.3 & 13.1 \\
SL19-04 & & 1.7 & -18 & 12.3 \\
SL19-06 & & -2.3 & -16.3 & 14.1 \\
SL19-17 & Bulk sample, $\mathrm{K}_{2} y^{1}$ & -0.1 & -18 & 12.4 \\
SL19-21 & & -2.4 & -18.1 & 12.2 \\
SL19-22 & & -2.9 & -20.4 & 9.9 \\
SL19-37 & & -5.2 & -17.4 & 13 \\
SL19-47 & & -5 & -11.1 & 19.4 \\
\hline ZKS5-5-2 & & -3.1 & -17.5 & 12.9 \\
ZKS25-61-1 & Carbonate vein, $\mathrm{K}_{2} y^{1}$ & -2.7 & -17.8 & 12.6 \\
ZKS5-5-1 & -3.3 & -18 & 12.3 \\
ZKS25-61-3 & & -2.6 & -16.3 & 14.1 \\
\hline SL20-39 & & -13 & -14.5 & 16 \\
SL20-40-1 & Dawsonite and & -13 & -15.4 & 15.1 \\
SL20-65-1 & ankerite, $\beta \mu$ & -13.1 & -14.7 & 15.7 \\
SL20-67 & & -16.6 & -18.2 & 12.2 \\
\hline ZKS1-41 & & -7.2 & -15.9 & 14.5 \\
SL20-40 & Calcite, $\beta \mu$ & -11.5 & -15.1 & 15.3 \\
SL20-65 & & -10.1 & -14.5 & 16 \\
\hline
\end{tabular}


Table 3. S isotopic compositions of pyrite from the Lower member of Yaojia Formation.

\begin{tabular}{|c|c|c|c|}
\hline Methods & Samples & $\begin{array}{l}\text { Lithology and } \\
\text { Stratigraphy }\end{array}$ & $\delta^{34} S(\%$ (\%) \\
\hline \multirow{4}{*}{ TIMS, sample dissolving } & SL19-06 & \multirow{3}{*}{ Bulk sample, $K_{2} y^{1}$} & 19.8 \\
\hline & SL19-37 & & -27.8 \\
\hline & SL19-47 & & -14.9 \\
\hline & $\begin{array}{l}\text { SL19-37 } \\
\text { SL19-47 }\end{array}$ & Pyrite grain, $\mathrm{K}_{2} y^{1}$ & $\begin{array}{l}-36.5 \\
-28.2\end{array}$ \\
\hline \multirow{18}{*}{ LA-ICP-MS, in-situ } & SL19-06-2 & \multirow{18}{*}{ Colloidal pyrite, $\mathrm{K}_{2} \mathrm{y}^{1}$} & 24.02 \\
\hline & SL19-06-3 & & 3.27 \\
\hline & SL19-06-4 & & -0.44 \\
\hline & SL19-06-5 & & 36.31 \\
\hline & SL19-06-6 & & 10.49 \\
\hline & SL19-06-7 & & 12.43 \\
\hline & SL19-06-8 & & 25.46 \\
\hline & SL19-06-9 & & 12.64 \\
\hline & SL19-37-1 & & -28.92 \\
\hline & SL19-37-2 & & -43.91 \\
\hline & SL19-37-3 & & -39.72 \\
\hline & SL19-37-4 & & 3.77 \\
\hline & SL19-37-5 & & -4.42 \\
\hline & SL19-37-6 & & -12.45 \\
\hline & SL19-47-1 & & -3.26 \\
\hline & SL19-47-2 & & -5.48 \\
\hline & SL19-47-3 & & 8.44 \\
\hline & SL19-47-4 & & 7.45 \\
\hline
\end{tabular}

Meanwhile, LA-ICP-MS method was used to conduct in-situ sulfur isotopic analysis of the pyrite selected in inclusion slices of three samples. The instruments were a Neptune Plus multireceiver plasma mass spectrometer (Thermo Scientific, Waltham, MA, USA) and an associated RESOlution SE $193 \mathrm{~nm}$ solid-state laser. Point dissolution was applied, with a diameter of $40 \mu \mathrm{m}$, an energy density of $7-8 \mathrm{~J} / \mathrm{cm}^{2}$, and a frequency of $6-8 \mathrm{~Hz}$. High purity of helium was used as carrier gas to blow the aerosol produced through denudation into the MC-ICP-MS for mass spectrometry analysis. ${ }^{32} \mathrm{~S}$ and ${ }^{34} \mathrm{~S}$ were received statically with a Faraday cup at the same time.

\subsection{Fluid Inclusion Analysis}

Petrography identification of fluid inclusion, homogenization temperature analysis, and freezing point temperature analysis were performed on inclusion slices of four tight sandstone samples (Table 4). First, the types and stages of inclusions were distinguished under fluorescence microscope observation using polarized light and excitated UV. The inclusions were soaked with alcohol, the gum was removed, and the slides were unloaded, after completion of the preliminary observation. Finally, the homogenization and last ice-melting temperature of inclusions in carbonate minerals or secondary fluid inclusions in fractures was measured on a British-made LINKAM THMS600 (Linkam, UK) coolingheating stage, with a temperature range of $-196^{\circ} \mathrm{C}$ to $600^{\circ} \mathrm{C}$ and an error of $\pm 0.1{ }^{\circ} \mathrm{C}$. The heating/freezing rate was $10^{\circ} \mathrm{C} / \mathrm{min}$ at temperatures below $100{ }^{\circ} \mathrm{C}$ and reduced to a rate of $5{ }^{\circ} \mathrm{C} / \mathrm{min}$ at temperatures exceeding $100^{\circ} \mathrm{C}$. Salinity of fluid was estimated according to the equations from Bodnar (1993) [24]. 
Table 4. S isotopic compositions of pyrite from the Lower member of Yaojia Formation. /: Not detected.

\begin{tabular}{|c|c|c|c|c|c|}
\hline Samples & Mineral & Inclusion Type & Size $(\mu \mathrm{m})$ & $\begin{array}{l}\text { Homogenization } \\
\text { Temperature }\left({ }^{\circ} \mathrm{C}\right)\end{array}$ & $\begin{array}{l}\text { Salinity }(w t \% \\
\mathrm{NaCl})\end{array}$ \\
\hline ZKH2-2-1 & \multirow{3}{*}{ Ankerite cement } & $\begin{array}{l}\text { two-phase (vapor-liquid) } \\
\text { inclusions }\end{array}$ & $\begin{array}{l}8 \times 11 \\
4 \times 6 \\
4 \times 6\end{array}$ & $\begin{array}{l}178 \\
166 \\
202\end{array}$ & $\begin{array}{c}9.98 \\
/ \\
6.59\end{array}$ \\
\hline ZKH0-2-4 & & & $\begin{array}{l}4 \times 8 \\
2 \times 5\end{array}$ & $\begin{array}{l}213 \\
232\end{array}$ & $\begin{array}{l}4.34 \\
4.18\end{array}$ \\
\hline KT14-25-1 & & $\begin{array}{l}\text { two-phase } \\
\text { (aqueous-rich) } \\
\text { inclusions }\end{array}$ & $\begin{array}{c}3 \times 5 \\
3 \times 25 \\
2 \times 14 \\
5 \times 9 \\
8 \times 5 \\
3 \times 6\end{array}$ & $\begin{array}{l}156 \\
100 \\
107 \\
111 \\
140 \\
198\end{array}$ & $\begin{array}{c}/ \\
5.56 \\
5.26 \\
/ \\
6.88 \\
6.72\end{array}$ \\
\hline \multirow[t]{2}{*}{ ZKS5-5 } & \multirow[t]{2}{*}{ Calcite cement } & $\begin{array}{l}\text { two-phase } \\
\text { (aqueous-rich) } \\
\text { inclusions }\end{array}$ & $\begin{array}{c}2 \times 5 \\
2 \times 3 \\
4 \times 6 \\
2 \times 6 \\
4 \times 16 \\
3 \times 14\end{array}$ & $\begin{array}{l}214 \\
223 \\
203 \\
215 \\
215 \\
213\end{array}$ & $\begin{array}{l}4.18 \\
4.34 \\
1.91 \\
1.91 \\
0.71 \\
0.71\end{array}$ \\
\hline & & $\begin{array}{c}\text { two-phase (vapor-liquid) } \\
\text { inclusions }\end{array}$ & $\begin{aligned} 13 & \times 18 \\
3 & \times 6\end{aligned}$ & $\begin{array}{l}234 \\
213\end{array}$ & $\begin{array}{l}1.91 \\
3.23\end{array}$ \\
\hline
\end{tabular}

The sulfur isotope analysis of in-situ pyrite was performed in Beijing Kehui Testing Technology Co., LTD. (Beijing, China) and the other samples were analyzed in Analytical Laboratory of Beijing Research Institute of Uranium Geology (BRIUG).

\section{Results}

\subsection{Hydrothermal Altered Minerals}

\subsubsection{Carbonatization}

Carbonation is extremely well developed in dolerite and tight sandstone of Yaojia Formation. They are mainly composed of calcite and ankerite, followed by dolomite, high-Fe dolomite, and ferromanganese dolomite, with a few of dawsonite (Table 1). At a macroscopic level, different types of white carbonate minerals are mainly veined in the flat fractures and fracture surfaces of dolerite, with mutual interlace and without obvious penetration (Figure 3a,b). They may have been derived from hydrothermal products in different evolution stages after one period of magmatic stage [23]. Different internal productions of carbonate mineral mixtures have been found in dolerite under microscope. Some calcites were produced in blocky or in straight veins with good crystal shape between different minerals such as plagioclase and pyroxene in dolerite (Figure 3c). Some other ankerite and dawsonite are parallelly distributed in comb, radial, colloidal, and bridging form (Figure 3d). Sandstones of the Yaojia Formation have diverse types of carbonate minerals, mostly in the form of cement on a macroscopic scale, with a small amount of micro-fine veins produced in flat (Figure 3e). Microscopically, the carbonate cements of calcite, ankerite, and dawsonite are gradually precipitated in succession (Figure 3f). In some cases, a gradual transition of harbor shape exists in distribution of ankerite, ferromanganese dolomite, and calcite and dolomite, which precipitated relatively earlier (Figure $3 \mathrm{~g}-\mathrm{h}$ ). All of the above indicate that the sandstones were subjected to intense hydrothermal alteration and various types of carbonate minerals may have been precipitated at diverse stages of evolution due to gradual changes in $\mathrm{Mg}, \mathrm{Ca}, \mathrm{Fe}$, and $\mathrm{Mn}$ cation concentrations [31]. Data from electron microprobe also show a relationship of wax and wane between ion contents of $\mathrm{Ca}$ and $\mathrm{Fe}, \mathrm{Mg}$, and $\mathrm{Mn}$ in carbonate minerals (Table 1). 


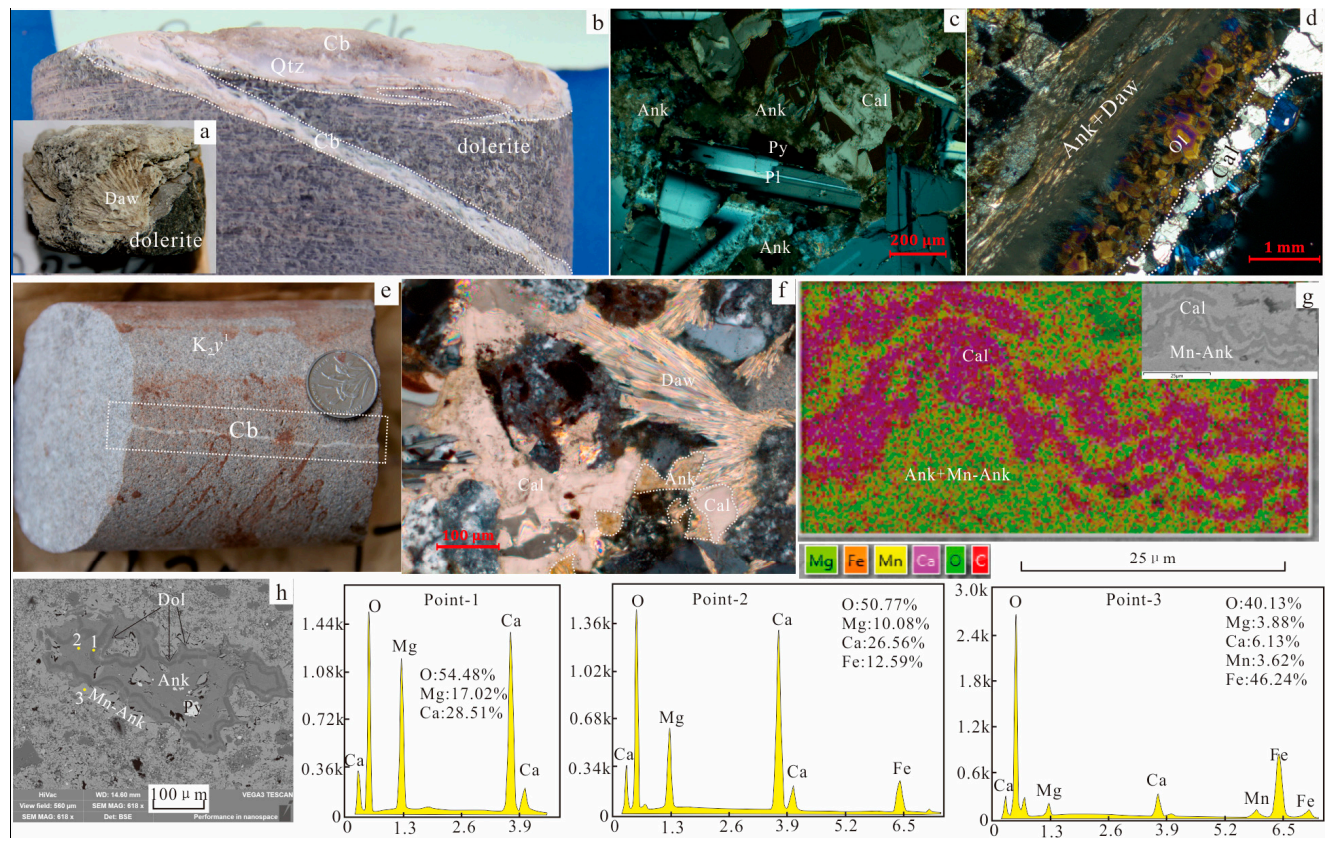

Figure 3. Macro-micrographs and energy spectra of dolerite and hydrothermal carbonate in the lower member of Yaojia Formation in Qianjiadian ore field. (a) Dolerite with radial dawsonite, (b) Dolerite bearing quartz and carbonate veins, (c) Dolerite with produces of pyrite, calcite and ankerite, (d) Dolerite with different types of carbonate veins, (e) Gray dense sandstone with late carbonate veinlets, $(\mathbf{f}-\mathbf{h})$ Progressive evolution of different carbonate minerals. Daw: dawsonite; $\mathrm{Cb}$ : carbonate; Qtz: quartz; Ank: ankerite; Cal: Calcite, Ol: olivine; Py: pyrite; Pl: plagioclase, Mn-Ank: ferromanganese dolomite; Dol: dolomite.

\subsubsection{Metal Mineralization}

Microscopic results indicate that some metal mineralization was produced in the rocks (Figures 3 and 4), including mineralization of pyrite, sphalerite, and clausthalite. Intergrowth of late-stage hydrothermal colloidal fine-grained pyrite and carbonatization is also identified in the dolerite of this area for the first time (Figure 3c), which directly verifies the reducibility of hydrothermal fluids [42]. Colloidal and vein-like hydrothermal pyrites are also found in a large distribution in the gray tight sandstone of the Yaojia Formation. Some pyrites are even found in granular form and produced in limonite cements in modified miscellaneous sandstone, with very good crystallization and without oxidation residual edge (Figure 4a). The presence of an oxidation event is indirectly indicated prior to the hydrothermal exudation. Some pyrite is colloidal and directly encapsulated in carbonate cements (Figure $3 \mathrm{~h}$ ). Meanwhile, sphalerite is also found in close symbiosis with ankerite in sandstone (Figure 4b), and fine-grained clausthalite is wrapped in homogeneous organic matter of hydrothermal genesis (Figure 4c).

\subsubsection{Silicification and Biotitization}

A few glassy siliceous veins were found, for the first time, intermittently wrapped in white carbonate mixed veins in dolerite (Figure 3b). Microscopic observation also reveals small amounts of pyrite, rutile, ilmenite, and other metallic minerals inside the cryptocrystalline quartz veins (Figure $4 \mathrm{~d}$ ). The quartz fragments of sandstones in the Yaojia Formation have undergone some dissolution, producing hydrothermal ankerite cements around them (Figure 4e). In some other parts, a large amount of fine-crystalline quartz is coeval with clausthalite, uranium-titanium-zircon mixture, calcite, ankerite, chlorite, etc., as a result of dissolution and recrystallization of quartz grains in sandstones under alkaline hydrothermal effect [43]. In addition, a small amount of striped muscovite has also undergone light-green biotitization under microscope, accompanying with ankerite 
in the periphery (Figure $4 \mathrm{f}$ ), representing typical hydrothermal alteration products of low-intermediate temperature $[44,45]$.

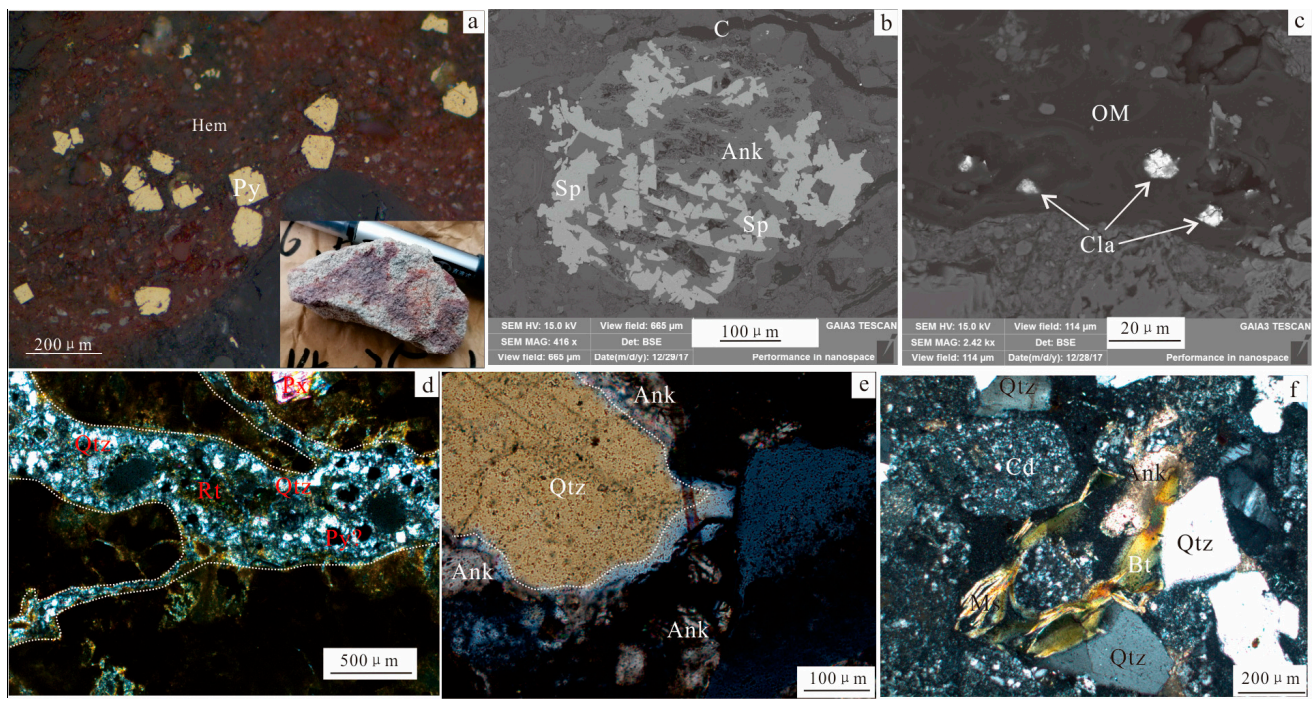

Figure 4. Macro-micrographs of hydrothermal alteration from dolerite and the lower member of Yaojia Formation in Qianjiadian ore field. (a) Hydrothermal pyrite is rapidly formed in oxidized sandstone, (b) Intergrowth of ankerite and sphalerite, (c) Selenite is wrapped in organic matter, (d) Siliceous veins containing metallic minerals, (e) Quartz fringe with alkaline dissolution and associated ankerite, (f) Biotitization of Muscovite. Hem: hematite; Py: pyrite; Ank: ankerite; Sp: sphalerite; OM: organic matter; Cla: selenite; Qtz: quartz; Rt: rutile; Px: pyroxene; Bt: biotite; Ms: muscovite, Cd: lithic debris.

\subsection{Hydrothermal Uranium Mineralization}

In the absence of direct evidence for hydrothermal superimposed alteration of mineralization in the study area in the past, some mineralogical and geochemical evidence of hydrothermal mineralization have been found in the hydrothermally altered tight sandstone ores for the first time, which directly demonstrates the involvement of hydrothermal fluids in the occurrence of uranium mineralization in the study area [27]. Microscopic identification shows that some bright white colloidal and rounded uraninites are on the edge of hydrothermal ankerite (Figure 5a,b), while the surrounding strawberry-shaped pyrite contains no uranium within or around (Figure 5a). Grayish-white uranium-rich euhedral ankerites are produced in the surrounding area. Mixtures of hydrothermal origin have been found locally (Figure 5c,d), including amorphous colloidal uranium- and zirconium-bearing mixtures, uranium- and titanium-bearing mixtures, and other materials (Figure 5e-g). Among them, uranium production is interwoven with zirconium and titanium, in a relationship of wax and wane (Figure $5 \mathrm{f}, \mathrm{g}$ ). Further results of electron microprobe analysis show that uraninites around ankerite have relative uranium contents of $70.87 \%-72.50 \%, \mathrm{SiO}_{2}$ contents of $0.83 \%-3.17 \%$, $\mathrm{TiO}_{2}$ content of $1.72 \%-1.98 \%$, and usually high levels of $\mathrm{ZrO}_{2}$ contents in the range of $5.06 \%-6.36 \%$ (Table 1). In addition, traces of uranium with a value of $0.05-0.13 \%$ have also been identified in some hydrothermal ankerite and ferromanganese dolomite, providing one of the direct evidence of hydrothermal carry of uranium. 

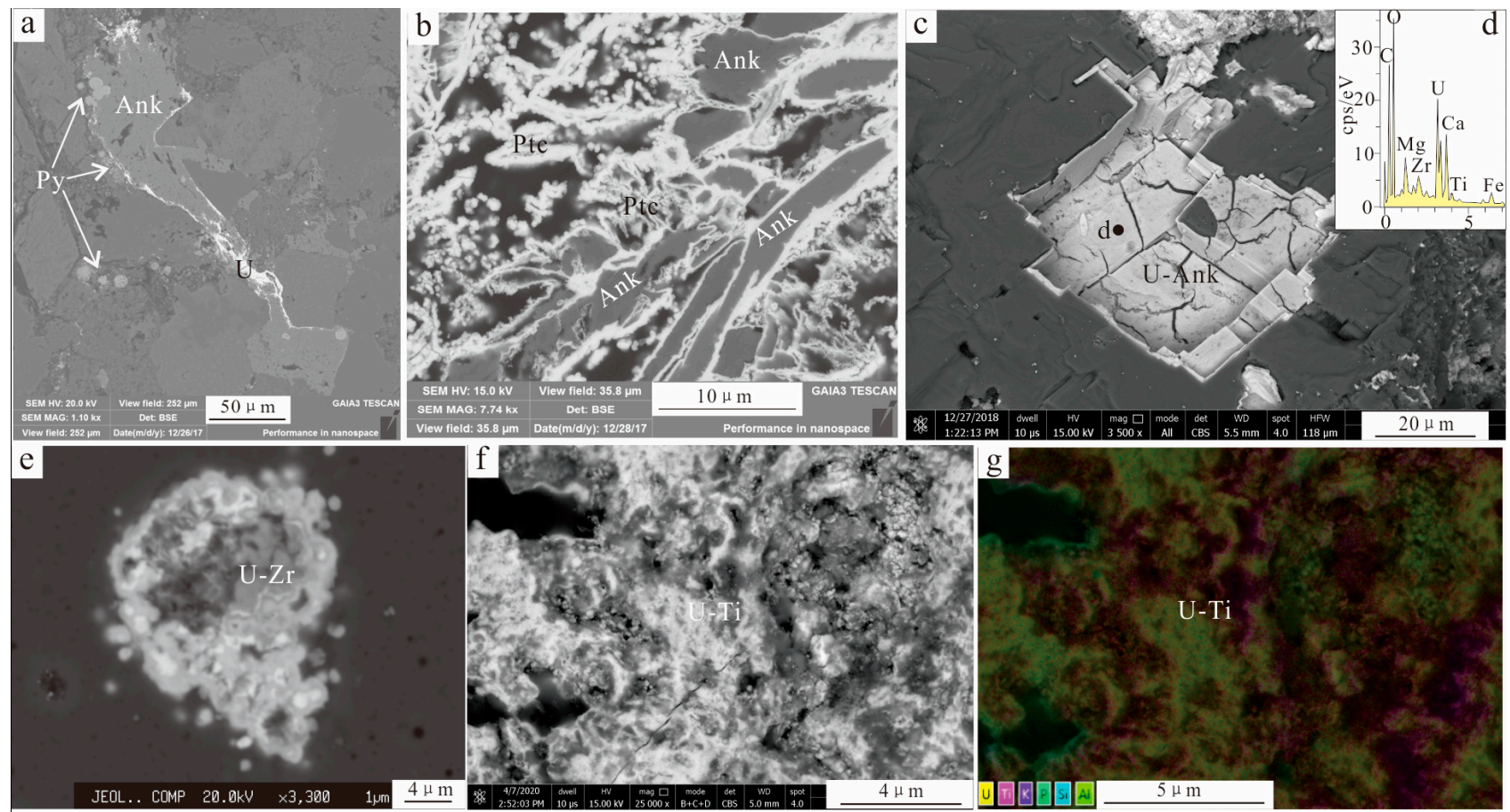

Figure 5. Micrographs of hydrothermal superimposed uranium mineralization from the lower member of Yaojia Formation in Qianjiadian ore field. (a,b) Pitchblende occurred at the edge of ankerite, (c,d) Euhedral uranium bearing iron dolomite and its energy spectrum, (e) Colloidal mixtures bearing uranium and zirconium, $(\mathbf{f}, \mathbf{g})$ Colloidal mixtures bearing uranium and titanium. Py: pyrite; Ptc: pitchblende; Ank: ankerite; U-Ank: uranium-bearing ankerite; U-Zr: mixtures containing uranium and zirconium; U-Ti: compound bearing uranium and titanium.

\subsection{Stable Isotopes \\ 4.3.1. C-O Isotope}

Carbon and oxygen isotopic composition of bulk rock and single carbonate mineral were measured on carbonate veins in dolerite and hydrothermally altered sandstone (Table 2), respectively, in order to trace the source and nature of hydrothermal fluids in the study area. The results show that the carbon and oxygen isotopic compositions of bulk sandstone and carbonate mineral grains are relatively consistent, with $\delta^{13} \mathrm{C}_{\mathrm{PDB}}$ from $-5.2 \%$ to $-1.7 \%$ and $-3.3 \%$ to $-2.6 \%$, respectively, and $\delta^{18} \mathrm{O}_{\mathrm{PDB}}$ from $-20.4 \%$ to $-11.1 \%$ and $-18 \%$ o to $-16.3 \%$, respectively. The carbon and oxygen isotopic compositions of different types of carbonate minerals in dolerite are also relatively consistent, but with some variations. The $\delta^{13} \mathrm{C}_{\mathrm{PDB}}$ ranges from $-16.6 \%$ to $-13 \%$ and $\delta^{18} \mathrm{O}_{\mathrm{PDB}}$ varies from $-18.2 \%$ to $-14.5 \%$ for a mixture of ankerite and dawsonite. The $\delta^{13} \mathrm{C}_{\mathrm{PDB}}$ of calcite is from $-11.5 \%$ to $-7.2 \%$ and $\delta^{18} \mathrm{O}_{\mathrm{PDB}}$ is from $-15.9 \%$ to $-14.5 \%$. It suggests significant differences in the carbon isotopic compositions of carbonate minerals in the sandstone of Yaojia Formation and dolerite (Figure 6), and thus indicating diverse carbon sources $[29,35]$. However, all of carbons are inorganic carbon [41]. This is obviously distinct from the other sandstone-type uranium ores in China where all carbon sources are organic carbon [16]. 


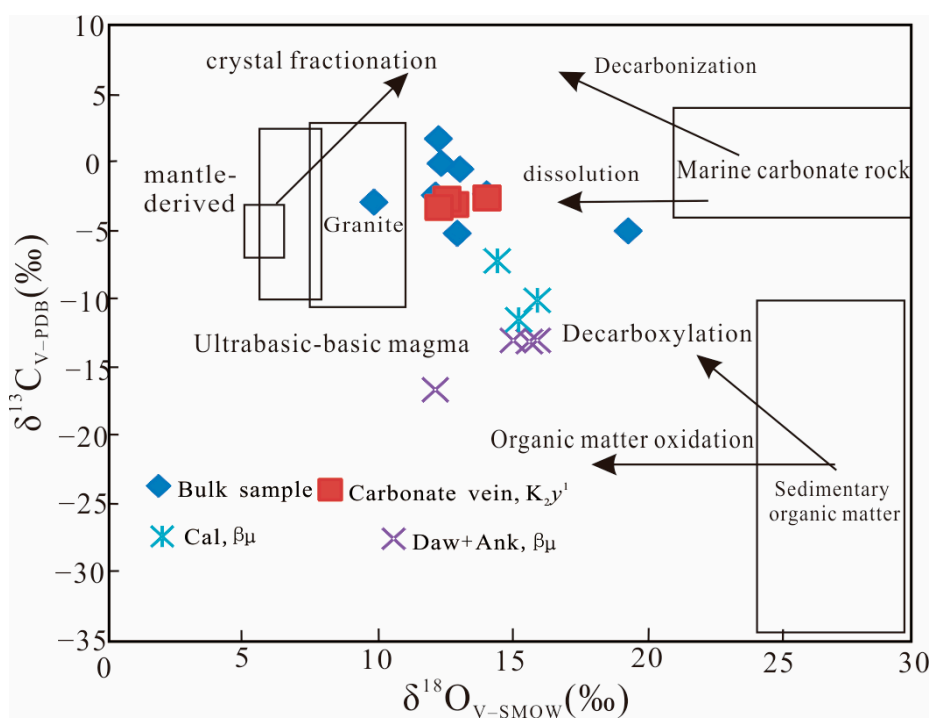

Figure 6. Diagram of $\mathrm{C}$ and $\mathrm{O}$ isotopic compositions of hydrothermal carbonates in Qianjiadian ore field (Basemap from [9]).

\subsubsection{Sulfur Isotope}

Bulk rock, single-mineral, and in-situ sulfur isotope results all indicate that pyrite in ore beds of the Yaojia Formation has two sources (Table 3), including bacterial sulfate reduction (BSR) and thermochemical sulfate reduction (TSR) with sulfur isotopes less than and greater than zero, respectively [33]. This is also generally consistent with the petrologic and mineralogical identification results. The sulfur isotopic composition of bulk rock sample SL19-6 is 19.8\%. The in-situ sulfur isotopic compositions measured by LA-ICP-MS are also overwhelmingly positive (Figure 7 ), ranging from $-0.44 \%$ to $36.3 \%$. This indicates that the majority of pyrite is hydrothermal product [4]. The sulfur isotopic compositions of the bulk rock and single-mineral SL19-37 sample are $-27.8 \%$ and $-36.5 \%$, respectively, with in-situ sulfur isotopic compositions from $-43.9 \%$ to $-3.78 \%$. It suggests that most of these pyrites may have been originated from low-temperature bacterial sulfate reduction and only a very small amount have possibly been modified by hydrothermal reduction (Figure 7). The sulfur isotopic compositions of the bulk rock and single-mineral SL19-47 sample are $-14.9 \%$ and $-28.2 \%$, respectively, indicating microbial origin [33]. The in-situ sulfur isotopic compositions range from $-5.49 \%$ to $-8.44 \%$, suggesting possible presence of minor hydrothermally produced pyrite.

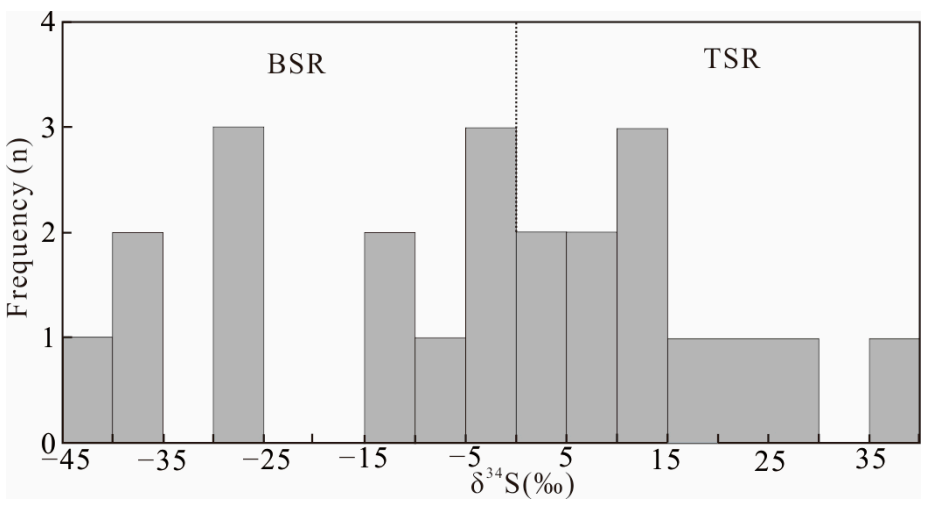

Figure 7. Histograms showing the distribution of $\delta^{34} S$ values from different genetic pyrites in Qianjiadian ore field. 


\subsection{Fluid Inclusions in the Calcite Cement}

\subsubsection{Petrographic Characteristics}

Both aqueous-rich phase and two-phase (vapor-liquid) fluid inclusions are found haphazardly produced in calcareous and ferrodolomitic cements in sandstones of the Yaojia Formation, with elliptical, quadrilateral, and irregular-shaped inclusions distributed in groups and a few produced banded and linear along the fractures (Figure 8). The size of two-phase (vapor-liquid) inclusions in ankerite is generally $4 \mu \mathrm{m} \times 6 \mu \mathrm{m}$, with a few up to $8 \mu \mathrm{m} \times 11 \mu \mathrm{m}$. Liquid-rich inclusions are generally in the range of $2 \mu \mathrm{m} \times 5 \mu \mathrm{m}$ and $5 \mu \mathrm{m} \times 9 \mu \mathrm{m}$. The size of gas-liquid two-phase inclusions in calcite is generally $3 \mu \mathrm{m} \times 6 \mu \mathrm{m}$ and the liquid-rich inclusions are generally from $2 \mu \mathrm{m} \times 3 \mu \mathrm{m}$ to $4 \mu \mathrm{m} \times 16 \mu \mathrm{m}$. In general, inclusions in carbonate minerals are dominated by transparent and colorless liquid-phase saline inclusions with ratios of gas over liquid less than $5 \%$, while a few are colorless-gray gas-liquid two-phase saline inclusions with ratios of gas over liquid less than $10 \%$. Considering the shallow burial depth of the stratum in geological history, generally no more than $1200 \mathrm{~m}$, we believe that the inclusions in plastic carbonate minerals were not deformed [24]. Thus, the measured homogeneous temperature and salinity of inclusions represent the properties of paleofluids.

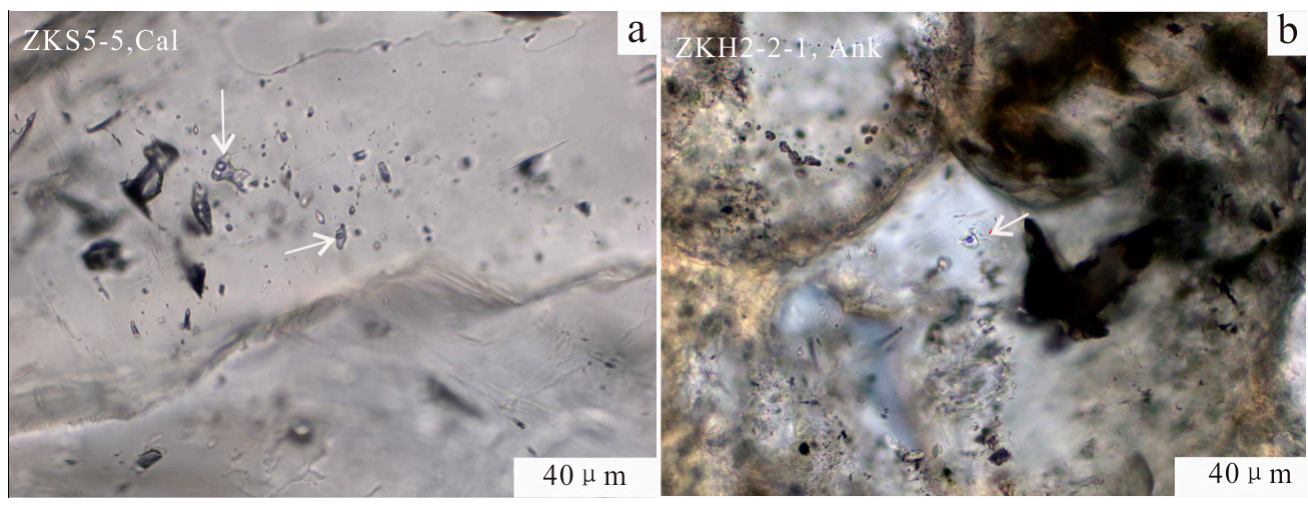

Figure 8. Two-phase (vapor and liquid) inclusions with a small size occur in the carbonate cement from the tight sandstone of the Lower member of Yaojia Formation. (a) Calcite bearing two-phase inclusions, (b) Ankerite bearing two-phase inclusions.

\subsubsection{Homogeneous Temperature and Salinity}

Homogeneous temperature and freezing point temperature analyses were performed on two-phase (aqueous-rich and vapor-liquid) fluid inclusions in calcite and ankerite cements, respectively (Table 4 ). The results show that the inclusions in ankerite have a homogeneous temperature of $100-232{ }^{\circ} \mathrm{C}$ in a wide range of values, but the temperature is generally low (Figure 9a). The overall salinity is high, in the range of $4.18 \%$ and $9.98 \%$ $\mathrm{NaCl}$, with a peak at $4-6 \% \mathrm{NaCl}$ (Figure $9 \mathrm{~b}$ ). The homogeneous temperature of fluid inclusions in calcite is generally high, with the values in the range of $203-234{ }^{\circ} \mathrm{C}$ (Figure 9a). However, salinity is overall low, in the range of $0.71-4.34 \% \mathrm{NaCl}$, with two peak intervals of $0-1$ and 3-5, respectively (Figure $9 \mathrm{~b}$ ). All the homogeneous temperatures of the above fluid inclusions are much higher than the maximum burial temperature of about $70{ }^{\circ} \mathrm{C}$ in geological history of the Yaojia Formation in the region [46], indicating that the secondary fluid inclusions in the carbonate cements are the products of the later thermal events. 

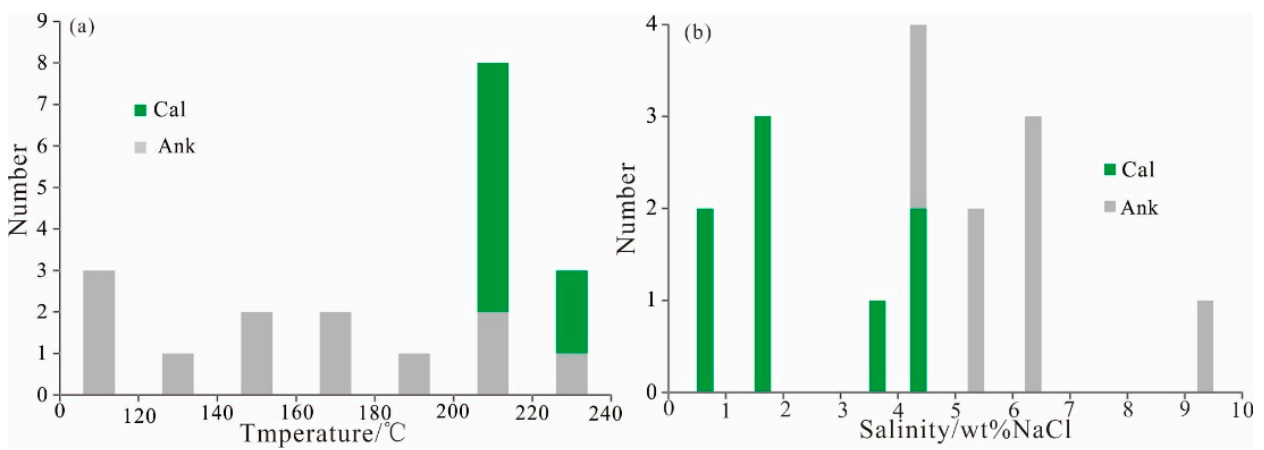

Figure 9. (a) Histogram of homogenization temperature values of aqueous inclusions in calcite and ankerite cements. (b) Histogram of salinity values of aqueous inclusions in calcite and ankerite cements.

\section{Discussion}

\subsection{Hydrothermal Fluid and Superimposed Mineralization}

The Qianjiadian ore field has developed obvious hydrothermal alteration [28]. Previous researchers have carried out studies on hydrothermally altered minerals and fluid properties in the Yaojia Formation. They found that several hydrothermal alteration mineral assemblages exist in the interior, including carbonatization, pyritization, and clayification $[26,31,35]$. The detailed petrographic and mineralogical identification in this study shows that intense carbonation occurs in both dolerite and sandstones of the Yaojia Formation (Figure $3 \mathrm{a}-\mathrm{g}$ ). They are mainly composed of calcite, dolomite, ankerite, and ferromanganese dolomite (Table 1). Different forms of hydrothermal pyrite can be seen in both rocks (Figures $3 \mathrm{c}$,h and $4 \mathrm{a}$ ), with positive values of sulfur isotope and a thermochemical origin characterized by enrichment of ${ }^{34}$ S isotope (Table 3, Figure 7) [42]. Simultaneously, white carbonate veins of dolerite often intermittently wrap some cryptocrystalline quartz veinlets inside (Figures $3 \mathrm{~b}$ and $4 \mathrm{~d}$ ). The phenomenon of dissolution in quartz fragments edge and recrystallization of fine crystalline quartz can be seen in hydrothermally altered sandstones (Figure 4e). These above collectively indicate that the deep hydrothermal fluids in this area are rich in $\mathrm{CO}_{3}{ }^{2-}$, alkaline, and strongly reductive [45,47], while the occurrence of small amounts of radial and acicular dawsonite in the dolerite and sandstone (Figure 3a,f) indicates that the hydrothermal fluids have a local extremely high fugacity of $\mathrm{CO}_{2}[48,49]$.

The different types of carbonate minerals in the Yaojia Formation are previously thought to be formed by the exudation of hydrothermal fluids of various properties in multiple phases [50], including three phases of Phase I calcite, Phase II ankerite, and Phase III high-Fe dolomite [31]. Our study indicates that they are more likely to be the products of successive precipitation of contemporaneous homologous hydrothermal fluids at different stages of long-term evolution, due to changes in their own internal $\mathrm{CO}_{2}$ fugacity, temperature, and concentration of cations such as $\mathrm{Mn}, \mathrm{Ca}, \mathrm{Fe}$, and $\mathrm{Mg}$ [51]. All the fluids were originated from post-magmatic hydrothermal fluids after the intrusion of intermediate-basic igneous rocks and generation of dolerite [23]. The evidence mainly include several aspects. Macroscopically, different types of carbonate minerals are simultaneously produced in the same vein (Figure 3b), without obvious macroscopic interpenetration relationship although some inclusions and metasomatism exist. Microscopically, calcite and other carbonate minerals are distributed in parallel with a clear interface (Figure 3d). The mixed veins of calcite, dolomite, ankerite, ferromanganese dolomite, and dawsonite in the sandstone are often accompanied with interlaced and gradual transition output or replacing distribution relationships of successive precipitation (Figure $3 \mathrm{f}-\mathrm{h}$ ) [21]. The results of electron microprobe analysis also show that content of $\mathrm{CaO}$ is negatively correlated with that of $\mathrm{MnO}, \mathrm{FeO}$, and $\mathrm{MgO}$ in different types of carbonate minerals in sandstones of the Yaojia Formation. To some degree, the content of $\mathrm{MnO}$ is also negatively correlated with that of $\mathrm{FeO}$ and $\mathrm{MgO}$ (Table 1), as a result of the gradual change of cation concentration in hydrothermal fluids [50]. 
Therefore, we believe that the process of hydrothermal carbonation in the area may be as follow. Temperature of hydrothermal fluids was high while salinity was low after magmatic period [44]. The $\mathrm{CO}_{3}{ }^{2-}$ content was unsaturated and the cations were mainly $\mathrm{Ca}^{2+}$ ions. Meanwhile, calcite was mainly formed at a relatively early stage (Figure 3f), with a short time of precipitation [18]. This is consistent with high homogeneous temperature $\left(>200{ }^{\circ} \mathrm{C}\right)$ and low salinity $(<4 \% \mathrm{NaCl})$ of fluid inclusions inside calcite and a relatively concentrated range of the two proxies in this study (Table 4, Figure 9). Pressure fusion of quartz, feldspar, biotite, zircon, apatite, titanium-containing minerals [31], and other types of fragments in the surrounding rocks was caused by the alkaline reducing fluid, resulting in a large amount of $\mathrm{Fe}, \mathrm{Mg}, \mathrm{Mn}, \mathrm{P}, \mathrm{Zr}$, Ti, and Si ions entered into the hydrothermal fluid [52], changing the geochemical properties of the hydrothermal fluid. The fugacity and salinity of $\mathrm{CO}_{2}$ in the fluid gradually became higher and $\mathrm{CO}_{3}{ }^{2-}$ content gradually changed from saturated to supersaturated [22]. The temperature also decreased slowly. Consequently, carbonate minerals such as dolomite, ankerite, high-Fe dolomite, ferromanganese dolomite, and dawsonite were formed successively (Figure 3f-h) [53], with a relatively long duration of precipitation in a later period [50], wrapping or replacing the calcite produced relatively earlier (Figure $3 c, g$ ). This is consistent with the overall low homogeneous temperature (less than $200{ }^{\circ} \mathrm{C}$ ) and high salinity (commonly greater than $4 \% \mathrm{NaCl}$ ) of fluid inclusions in ankerite measured in this study (Table 4, Figure 9), as well as a wide range of values of the two proxies. In addition, this is also consistent with the result that the clastic apatite of the Yaojia Formation in the area was in thermal alteration annealing for a long time during the Paleogene [24], indirectly indicating the long duration of hydrothermal activity after the intermediate-basic magmatic period in the area. Carbon isotopes can be used to trace the origin of carbon in carbonate cements and thus identify fluid properties [19]. The carbon isotopic compositions of different types of carbonate minerals in dolerite in this study range from $-16.1 \%$ to $-7.2 \%$ (Table 2 ), demonstrating the carbon may have been mainly derived from inorganic carbon in the later stages of evolution of intermediate-basic magmas (Figures 2 and 6) [30]. Different types of carbonate cements in the sandstone are the products of $\mathrm{CO}_{2}$-rich hydrothermal fluids generated by degassing of dolerite mixed with atmospheric precipitation (Figure 6) [29], with carbon isotopic compositions in the range of $-5.2 \%$ and $-1.7 \%$ (Table 2 ). Various sources of carbon include (1) postmagmatic hydrothermal fluids, (2) redissolution of primary carbonate fragments in the Yaojia Formation, (3) weathering of carbonate-bearing parent rocks in the erosion source area and infiltration of the $\mathrm{CO}_{3}{ }^{2-}$ into the Yaojia Formation.

\subsection{Effects of the Hydrothermal Fluids on Uranium Mineralization}

In the southwestern Songliao Basin, the dolerite of the Qianjiadian uranium field overlaps with the uranium mineralization area in the plane (Figure 2a) [30]. Several drilling holes in the section reveal that the dolerite veins are interspersed in the Yaojia Formation in the form of dendrites and walls (Figure 2b), and finally intruded and pinched out in the Nengjiang Formation in the form of layers and caps [31]. Previous researchers proposed that the age of dolerite produced in this area is mainly concentrated in 45.8-53 Ma [23]. In approximate to the time of formation of the regional Shuangliao Basalt Group, the dolerite and basalt should be the products of the same phase of magmatic activity in the Eocene [21]. This timing is also consistent with the results of re-warming and annealing of clastic apatite in sandstones of the Yaojia Formation in this area during the Paleogene [54]. Four stages of mineralization ages exist in the Qianjiadian ore field, on basis of regional tectonic evolution history and bulk rock $\mathrm{U}-\mathrm{Pb}$ isotopic ages of ore obtained by previous authors $[25,30,38,40]$. The four stages include phase of diagenesis and pre-enrichment $(87 \pm 12 \mathrm{Ma}$ and $81.2 \pm 2.6 \mathrm{Ma})$, phase of hydrocarbon seepage and shallow-water oxidized mineralization $(74.5 \pm 4.8 \mathrm{Ma}$ and $67 \pm 5 \mathrm{Ma})$, primary mineralization phase of regionally interstratified oxidized mineralization (from $53 \mathrm{Ma}$ to $28 \mathrm{Ma}$ ), and phase of continuously oxidized and superposed modification (from $19 \mathrm{Ma}$ to $3 \mathrm{Ma}$ ). It can be seen that the primary mineralization stage of regionally interstratified oxidized mineralization 
is basically consistent with the timing of large-scale intrusion of dolerite (ca.50 Ma) [54], and they may have a responsive relationship in time chain. Collectively, the Qianjiadian ore field and the dolerite intrusion are closely linked in terms of spatial and temporal relationships (Figure 10). The post-magmatic hydrothermal activities played a constructive role in actively promoting uranium mineralization.

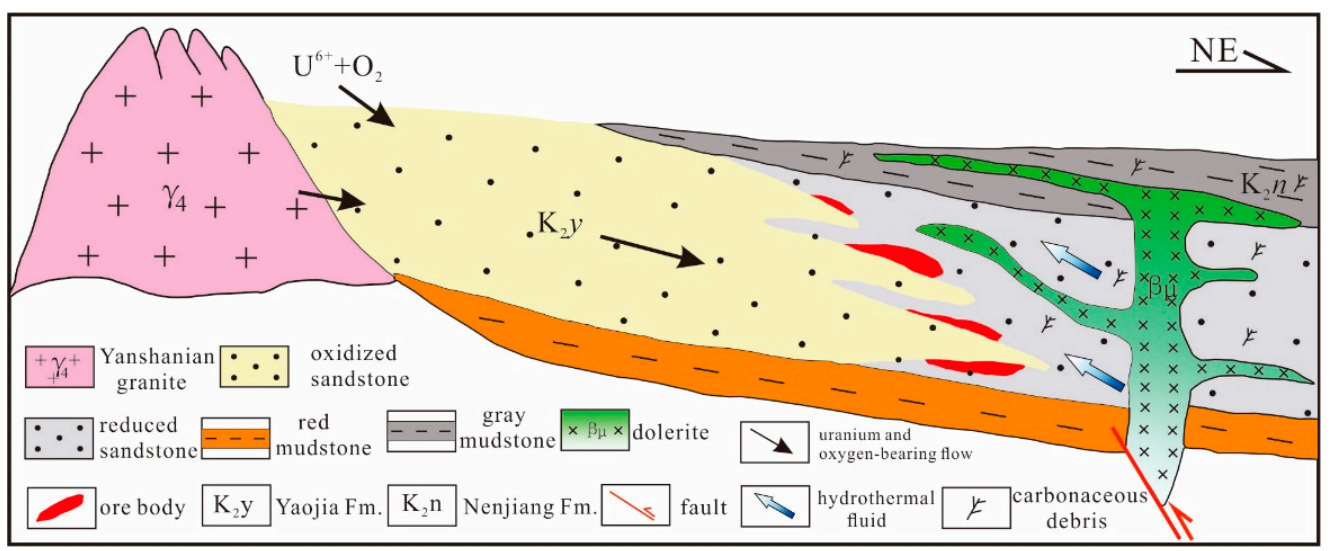

Figure 10. Generalized model showing the relationship between dolerite intrusion and uranium mineralization in Qianjiadian ore field.

Direct evidence of hydrothermal involvement in mineralization has long been missing in ore deposit horizon of the Yaojia Formation, due to a small number of hydrothermally altered ore samples and the difficulty of microscopic identification of uranium minerals. This study provides obvious mineralogical and elemental geochemical evidence of hydrothermal superimposed alteration mineralization in a later period [12]. The main evidence is as follows. A large amount of uraninite is microscopically visible at the edge of hydrothermal ankerite (Figure 5a-b), with local euhedral uranium-bearing ankerite (Figure $5 c-d$ ) and colloidal U-Zr-Si-Ti mixtures (Figure 5e-g). The electron probe analysis also shows that these uraninites contain a high abundance of $\mathrm{ZrO}_{2}$ and $\mathrm{TiO}_{2}$ internally, and all of the hydrothermal ankerites contain trace amounts of uranium (Table 1). Analysis result suggests that hydrothermal activities in the Paleogene changed the physicochemical environment of the sandstone fluids of the Yaojia Formation in the mining area (Figure 10) and destabilized the previously formed uranium minerals [54]. As a result, the $\mathrm{CO}_{3}{ }^{2-}, \mathrm{Ca}^{2+}$, and $\mathrm{U}(\mathrm{VI})$ in the hydrothermal fluids formed stable complexes of $\mathrm{Ca}_{2} \mathrm{UO}_{2}\left(\mathrm{CO}_{3}\right)_{3}$ and $\mathrm{CaUO}_{2}\left(\mathrm{CO}_{3}\right)_{3}{ }^{2-}$ under high temperature and restarted to migrate [55]. The uranium-bearing carbonate precipitates would be produced when the $\mathrm{CO}_{3}{ }^{2-}$ concentration of solution was gradually increased to oversaturated (Figure 5c). With the gradual decrease of temperature and pressure, the uranium ore was able to re-precipitate under weaker reducing conditions and attach to surroundings of the ankerite that had precipitated earlier (Figure 5a-b) [56]. Meanwhile, alkaline hydrothermal fluids would also produce hydrothermal-type mixtures (Figure $5 \mathrm{e}-\mathrm{g}$ ) containing uranium, zirconium, silicon, and titanium, accompanied by fine crystalline secondary quartz, pyrite, sphalerite, clausthalite, biotite, daphnite, and other hydrothermal alteration mineral assemblages in low-medium temperature [52,57].

In addition, thermal events in the study area may have played several roles on sandstone-type uranium mineralization as follows. (1) Thermal fluids not only brought a large amount of exotic reducing agents, such as a great deal of hydrothermally produced pyrite [45], but also accelerated the thermal evolution of carbonaceous organic matter in the strata of the Yaojia Formation, promoting hydrocarbon production and discharge. A mass of pyrolytic hydrocarbon fluids would further accelerate precipitation and enrichment of uranium [58]. Previous workers also found that some carbonaceous organic matter in the target layer have a high vitrinite reflectance, with Ro $>0.5 \%$ [46], and may have been altered by heat. In this study, residual inert groups in the altered sandstones were consolidated 
to form vein bodies of homogeneous amorphous organic matter [14]. These veins were filled in rock fissures or pores in the form of embayment and spatially coeval with or not far from the primary solid carbon fragments (Figure 4b), revealing obvious characteristics of post generation. Microscopic identification shows that the homogeneous organic matter was also encapsulated with hydrothermal fine-grained spherical clausthalite (Figure 4c), indicating its complexing and migrating effect on metal ions [51]. (2) The tight dolerite is characterized by low porosity and low permeability, and thus used as a good water retention layer [21]. As a result, sufficient time was provided for interaction of reducing material and oxygen- and uranium-bearing fluids in ore deposit horizon of the Yaojia Formation [30]. A large amount of uranium may have been accumulated, precipitated, and enriched around the gray residue as the water-rock reaction time was prolonged, forming a uranium mineralization zone of more than ten kilometers in the area (Figure 10). On the other hand, the intrusion of dolerite brought a large amount of carbonate minerals filled into the intergranular pores of the sandstone [22], and thus reduced the permeability of the sandstone (Figure 10), resulting in incomplete oxidation of the sand body and formation of gray sandstone residue and some tight sandstone ore.

\section{Conclusions}

(1) The Yaojia Formation in Qianjiadian ore field has been altered by low-medium temperature alkaline reducing fluids derived from the intrusion of intermediate-basic magma to form dolerite in the Paleogene. Different types of hydrothermally altered mineral assemblages in low-medium temperature were formed, including carbonatization, silicification, pyritization, sphalerite mineralization, clausthalite mineralization, and biotitization. As a result, local uraninite was accumulated at the rims of ankerite, with a series of hydrothermal superposed alteration mineralization of uranium-bearing ankerite, and uranium-, zirconium-, silicon-, and titanium-containing mixtures.

(2) Different types of hydrothermal carbonate minerals in the study area were gradually precipitated by hydrothermal fluids in the long-term evolutionary stages due to changes in $\mathrm{CO}_{2}$ fugacity, temperature, and concentration of various cations, in the generation sequence of calcite, dolomite, ankerite, high-iron dolomite, ferromanganese dolomite, and dawsonite. The carbonate minerals in the dolerite were mainly derived from hydrothermal fluids of intermediated-basic magmatic phase in a later period, with carbon and oxygen isotopic compositions from $-16.1 \%$ o to $-7.2 \%$ and from $-18.2 \%$ to $-14.5 \%$, respectively. The carbonate cements in the altered sandstone are mixed products of hydrothermal fluids from magma and atmospheric precipitation, with carbon and oxygen isotopic compositions from $-5.2 \%$ to $-1.7 \%$ and from $-20.4 \%$ o to $-11.1 \%$, respectively. Pyrite has two origins, including low-temperature bacterial sulfate reduction and thermochemical sulfate reduction. The latter has obviously strong enrichment of ${ }^{34} \mathrm{~S}$ isotope.

(3) The fluid inclusions in calcite of altered sandstones of the Yaojia Formation have high a homogeneous temperature $\left(203-234^{\circ} \mathrm{C}\right)$ and low salinity $(0.71-4.34 \% \mathrm{NaCl})$ with concentrated values, while the fluid inclusions in ankerite have an overall low homogeneous temperature $\left(100-232{ }^{\circ} \mathrm{C}\right)$ and high salinity $(4.18-9.98 \% \mathrm{NaCl})$ with dispersed values. This feature is consistent with the evolution process of hydrothermal fluid.

(4) The hydrothermal activities in the study area are closely related to the spatial and temporal distribution and genesis of sandstone-type uranium mineralization. Hydrothermal exudation in multiple episodes has a constructive effect on uranium mineralization through directly superimposing and altering the early formed uranium ore bodies, providing exotic reducing agents, promoting pyrolysis of carbonaceous fragments to produce and expel hydrocarbons, accelerating the precipitation and enrichment rate of uranium, as well as regional water stagnation and prolonging the water-rock reaction time. 
Author Contributions: Conceptualization, M.-K.Q. and S.-H.H.; data curation, J.-L.L.; formal analysis, Z.-Y.L.; investigation, W.-J.J. and Q.G.; methodology, M.-K.Q. and S.-H.H.; project administration, M.-K.Q. and J.-L.L.; resources, M.-K.Q. and W.-J.J.; supervision, L.-C.J.; writing-original draft, S.H.H.; writing-review and editing, M.-K.Q. and S.-H.H. All authors have read and agreed to the published version of the manuscript.

Funding: This study was jointly funded by the Development of Nuclear Research Project, Grant number 2017-1403 and the Fourth Talent Project from China National Nuclear Corporation, Grant number QNNC2102.

Data Availability Statement: No new data were created in this study. Data sharing is not applicable to this article.

Acknowledgments: The authors thank geology party No. 243 of CNNC for providing the ore samples and many useful data. We would also like to thank the anonymous reviews for their constructive comments and suggestions on the manuscript.

Conflicts of Interest: The authors declare no conflict of interest.

\section{References}

1. Ren, Z.L.; Zhang, S.; Gao, S.L.; Cui, J.P.; Liu, X.S. Relationship between thermal history and various energy mineral deposits in Dongsheng area, Yimeng uplift. Oil Gas Geol. 2006, 27, 187-193.

2. Cuney, M. Evolution of uranium fractionation processes through time; driving the secular variation of uranium deposit types. Econ. Geol. 2010, 105, 553-569. [CrossRef]

3. Cai, C.F.; Dong, H.L.; Li, H.T. Mineralogical and geochemical evidence for coupled bacterial uranium mineralization and hydrocarbon oxidation in the Shashagetai Deposit, NW China. Chem. Geol. 2007, 236, 167-179. [CrossRef]

4. Lan, Q.; Hu, R.Z.; Bi, X.W.; Liu, H.; Xiao, J.F.; Fu, S.L.; Santosh, M.; Tang, Y.Y. The source of organic matter and its role in producing reduced sulfur for the giant sediment-hosted Jinding zinc-lead deposit, Lanping Basin, Yunnan, southwest China. Econ. Geol. 2021, 116, 1537-1560. [CrossRef]

5. Sillitoe, R.H.; Brogi, A. Geothermal systems in the Northern Apennines, Italy; modern analogues of carlin-style gold deposits. Econ. Geol. 2021, 116, 1491-1501. [CrossRef]

6. Chi, G.X.; Xue, C.J. Hydrodynamic regime as a major control on localization of uranium mineralization in sedimentary basins. Science China. Earth Sci. 2014, 57, 2928-2933.

7. Granger, H.C.; Santos, E.S.; Dean, B.G.; Moore, F.B. Sandstone-type uranium deposits at Ambrosia Lake, New Mexico; an interim report. Econ. Geol. 1961, 56, 1179-1210. [CrossRef]

8. Qin, M.K.; He, Z.B.; Liu, Z.Y.; Guo, Q.; Song, J.Y.; Xu, Q. Study on Metallogenic Environments and Prospective Direction of Sandstone Type Uranium Deposits in Junggar Basin. Geol. Rev. 2017, 63, 1255-1269.

9. Huang, S.H.; Qin, M.K.; Xu, Q.; He, Z.B.; Guo, Q. Hydrocarbon Fluid Geological Characteristics of the Xishanyao Formation and Its Uranium Metallogenic Significance, Northwest Junggar Basin. Earth Sci. 2019, 44, 3060-3073.

10. Lin, S.X.; Gong, X.F.; Zhang, T.L. Deep Geofluid and Uranium Metallogenesis in Meso-Cenozoic Basin. Uranium Geol. 2017, 33, 321-328.

11. Fuchs, S.; Schumann, D.; Williams-Jones, A.E.; Vali, H. The growth and concentration of uranium and titanium minerals in hydrocarbons of the Carbon Leader Reef, Witwatersrand Supergroup, South Africa. Chem. Geol. 2015, 393-394, 55-66. [CrossRef]

12. Goswami, S.; Bhagat, S.; Zakaulla, S.; Kumar, S.; Rai, A.K. Role of organic matter in uranium mineralisation in Vempalle dolostone; Cuddapah basin, India. J. Geol. Soc. India 2017, 89, 145-154. [CrossRef]

13. Xu, Q.; Qin, M.K.; Fan, H.H.; Gu, D.Z.; Wang, S.Y. Preliminary discussion on ore-controlling factors of Azelik sandstone type uranium deposits in Niger. World Nucl. Geosci. 2012, 29, 149-155.

14. Liu, Z.Y.; Peng, S.P.; Qin, M.K.; He, Z.B.; Guo, Q.; Xu, Q. Multistage Enrichment of the Sawafuqi Uranium Deposit: New Insights into Sandstone-hosted Uranium Deposits in the Intramontane Basins of Tian Shan, China. Acta Geol. Sin. (Engl. Ed.) 2017, 6, 2138-2152. [CrossRef]

15. Xiao, X.J.; Li, Z.Y.; Fang, X.H.; Ou, G.X.; Sun, Y.; Chen, A.P. The Evidences and Significances of Epithermal Mineralization Fluid in the Dongsheng Sandstone Type Uranium Deposit. Bull. Mineral. Petrol. Geochem. 2004, 23, 301-304.

16. Zhu, Q.; Yu, R.A.; Feng, X.X.; Li, J.G.; Sima, X.Z.; Tang, C.; Xu, Z.L.; Liu, X.X.; Si, Q.H.; Li, G.Y.; et al. Mineralogy, geochemistry, and fluid action process of uranium deposits in the Zhiluo Formation, Ordos Basin, China. Ore Geol. Rev. 2019, 111, 102984. [CrossRef]

17. Wang, F.G.; Hou, S.R.; Zhang, L.; Men, H.; Wang, J.L. Study on the Characteristics of Water-Rock Interaction and Its Relation to Uranium Mineralization in Tamusu Uranium Deposit, Southern Bayin Gobi Basin. Geol. Rev. 2018, 64, $633-646$.

18. Zhang, C.Y.; Nie, F.J.; Jiao, Y.Q.; Deng, W.; Peng, Y.B.; Hou, S.R.; Dai, M.J.; Ye, T.F. Characterization of ore-forming fluids in the Tamusu sandstone-type uranium deposit, Bayingobi Basin, China: Constraints from trace elements, fluid inclusions and C-O-S isotopes. Ore Geol. Rev. 2019, 111, 102999. [CrossRef] 
19. Zhang, Z.M.; Cai, Y.Q.; Cai, J.F.; Liu, Z.Y. Discussion on the relationship between diabase intrusion and sandstone-type uranium mineralization in the southwestern Songliao Basin: C-O isotope evidence from carbonate cement. Geol. Rev. 2019, 65, 113-114.

20. Li, Z.Y.; Fang, X.H.; Chen, A.P.; Ou, G.X.; Sun, Y.; Zhang, K.; Xia, Y.L.; Zhou, W.B.; Chen, F.Z.; Li, M.G. Superposition metallogenic model of sandstone-type uranium deposit in the Northeastern Ordos basin. Uranium Geol. 2009, 25, 65-70.

21. Liu, C.; Xie, Q.B.; Wang, G.W.; Song, Y.F.; Wang, Y.H.; Tang, Y. Diagenetic and metamorphic characteristics and implications for hydrocarbon reservoirs in the country rocks influenced by magmatic emplacement: A case study from an outcrop of diabase intrusion in the southern Songliao Basin. Chin. J. Geol. 2017, 52, 453-469.

22. Gao, Y.Q.; Liu, L.; Zhang, S.H.; Yue, K.; Sun, X.M. Alteration to semi-concreted sandstone by diabase intrusion -taking an example from the cretaceous in the southeast of Songliao Basin. Xinjiang Geol. 2003, 21, 474-478.

23. Liu, H.B.; Jin, G.S.; Han, J.; Zhang, J.F.; Li, J.J.; Zhang, J.; Shi, X. Element and isotope geochemical characteristics of diabase in Qianjiadian uranium deposit. World Nucl. Geosci. 2021, 38, 135-143.

24. Rong, H.; Jiao, Y.Q.; Wu, L.Q.; Zhao, X.F.; Gao, M.Q.; Liu, W.H. Effects of igneous intrusions on diagenesis and reservoir quality of sandstone in the Songliao Basin, China. Mar. Pet. Geol. 2021, 127, 104980. [CrossRef]

25. Xia, Y.L.; Zheng, J.W.; Li, Z.Y.; Li, L.Q.; Tian, S.F. Metallogenic characteristics and metallogenic model of Qianjiadian uranium deposit in Songliao Basin. Miner. Depos. 2010, 29, 154-155.

26. Wu, R.G.; Xu, Z.; Gong, W.J.; Cai, J.F.; Ning, J. Discussion on the Genesis of Baixintu Uranium Deposit in Sonliao Basin. Uranium Geol. 2012, 28, 142-147.

27. Ding, B.; Liu, H.X.; Liu, Z.Y.; Qiu, L.F.; Jia, L.C.; Zhang, Z.M. Discovery of swartzite in Baolongshan uranium deposit in Songliao Basin and new way of sandstone-type uranium mineralization. Geol. China 2020, 48, 966-967.

28. Rong, H.; Jiao, Y.Q.; Wu, L.Q.; Ji, D.M.; Li, H.L.; Zhu, Q.; Cao, M.Q.; Wang, X.M.; Li, Q.C.; Xie, H.L. Epigenetic Alteration and Its Constraints on Uranium Mineralization from the Qianjiadian Uranium Deposit, Southern Songliao Basin. Earth Sci. 2016, 41, 153-166.

29. Jia, J.M.; Rong, H.; Jiao, Y.Q.; Wu, L.Q.; Guo, X.J.; Cao, M.Q.; Cui, Z.J.; Tao, Z.P. Occurrence of Carbonate Cements and Relationship between Carbonate Cementation and Uranium Mineralization of Qianjiadian Uranium Deposit, Songliao Basin. Earth Sci. 2018, 43, 149-161.

30. Yan, X.L. Characteristics of upper Cretaceous diabase and uranium mineralization in Qianjiadian area, Songliao Basin. J. Northeast. Pet. Univ. 2018, 42, 40-48.

31. Nie, F.J.; Yan, Z.B.; Xia, F.; Li, M.G.; Lu, Y.Y.; Cai, J.F.; Guo, F.N.; Ning, J. Hot fluid flows in the sandstone-type uranium deposit in the Kailu basin, Northeast China. Geol. Bull. China 2017, 36, 1850-1866. [CrossRef]

32. Chen, Z.Y.; Li, Q.C.; Liu, M.Y.; Song, B.; Cao, M.; Wang, M. Uranium mineralization formed through multi-stage superposition: Case of the Qianjiadian deposit in Songliao Basin, China. Energy Geosci. 2021, 2, 32-40. [CrossRef]

33. Bonnetti, C.; Zhou, L.L.; Riegler, T.; Brugger, J.; Fairclough, M. Large $\mathrm{S}$ isotope and trace element fractionations in pyrite of uranium roll front systems result from internally-driven biogeochemical cycle. Geochim. Et Cosmochim. Acta 2020, 282, 113-132. [CrossRef]

34. Liu, J.L.; Qin, M.K.; Cai, Y.Q.; Liu, Z.Y.; Zhang, Z.M.; Yao, L. Late Mesozoic tectonic evolution of the southern Great Xing'an Range, northeastern China: Constraints from detrital zircon $\mathrm{U}-\mathrm{Pb}$ and $\mathrm{Hf}$ isotopes of Late Cretaceous sandstones in the southwestern Songliao Basin. Geol. J. 2020, 55, 4415-4425. [CrossRef]

35. Jia, J.M.; Rong, H.; Jiao, Y.Q.; Wu, L.Q.; Wang, Y.; Li, H.L.; Cao, M.Q. Mineralogy and geochemistry of carbonate cement in sandstone and implications for mineralization of the Qianjiadian sandstone-hosted uranium deposit, southern Songliao Basin, China. Ore Geol. Rev. 2020, 123, 103590. [CrossRef]

36. Cai, J.F.; Yan, Z.B.; Zhang, L.L.; Feng, Z.B.; Huang, X.; Nie, F.J.; Xia, F. Relationship Between Grey Sandstone and Uranium Mineralization in Yaojia Formation of Upper Cretaceous in Tongliao, Inner Mongolia. J. East China Univ. Technol. 2018, 41, 328-335.

37. Lin, J.R.; Tian, H.; Dong, W.M.; Xia, Y.L.; Zheng, J.W.; Qi, D.N.; Yao, S.C. Original geochemical types and epigenetic alteration of rocks in prospecting target stratum for uranium deposit in the southeast of Songliao basin. Uranium Geol. 2009, 25, $202-207$.

38. Luo, Y.; Ma, H.F.; Xia, Y.L.; Zhang, Z.G. Geologic characteristics and metal logenic model of Qianjiadian uranium deposit in Songliao basin. Uranium Geol. 2007, 23, 193-200.

39. Xu, Z.L.; Li, J.G.; Zhu, Q.; Wei, J.L.; Li, H.L.; Zhang, B. Late Cretaceous paleoclimate change and its impact on uranium mineralization in the Kailu Depression, southwest Songliao Basin. Ore Geol. Rev. 2019, 104, 403-421. [CrossRef]

40. Zhang, M.Y.; Zheng, J.W.; Tian, S.F.; Xia, Y.L.; Liu, H.B. Research on existing state of uranium and uranium ore-formation age at Qianjiadian uranium deposit in Kailu depression. Uranium Geol. 2005, 21, 213-218.

41. Wang, B.; Tian, W.; Fu, B.; Fang, J.Q. Channelized $\mathrm{CO}_{2}$-Rich Fluid Activity along a Subduction Interface in the Paleoproterozoic Wutai Complex, North China Craton. Minerals 2021, 11, 748. [CrossRef]

42. Lin, S.R.; Hu, K.; Cao, J.; Bai, T.; Liu, Y.; Han, S.C. An in situ sulfur isotopic investigation of the origin of Carlin-type gold deposits in Youjiang Basin, southwest China. Ore Geol. Rev. 2021, 134, 104187. [CrossRef]

43. Nikiforov, A.V.; Dubinina, E.O.; Polyakov, N.A.; Sugorakova, A.M.; Khertek, A.K. Influence of Host Marble Rocks on the Formation of Intrusive Alkaline Rocks and Carbonatites of Sangilen (E. Siberia, Russia). Minerals 2021, 11, 666. [CrossRef]

44. Troshin, Y.P.; Lomonosov, I.S.; Bryukhanova, N.N. Conditions of formation of ore-geochemical specialization of modern hydrotherms in the Baikal rift zone. Russ. Geol. Geophys. 2008, 49, 169-175. [CrossRef] 
45. Ming, X.R.; Liu, L.; Yu, M.; Bai, H.G.; Yu, L.; Peng, X.L.; Yang, T.H. Bleached mudstone, iron concretions, and calcite veins: A natural analogue for the effects of reducing $\mathrm{CO}_{2}$-bearing fluids on migration and mineralization of iron, sealing properties, and composition of mudstone cap rocks. Geofluids 2017, 16, 1017-1042. [CrossRef]

46. Rong, H.; Jiao, Y.Q.; Wu, L.Q.; Wan, D.; Cui, Z.J.; Guo, X.J.; Jia, J.M. Origin of the carbonaceous debris and its implication for mineralization within the Qianjiadian uranium deposit, southern Songliao Basin. Ore Geol. Rev. 2019, 107, 336-352. [CrossRef]

47. Pointer, C.; Achworth, J.R.; Simpson, P.R. Genesis of coffinite and the U-Ti association in lower Old Red Sandstone sediments, Ousdale, Caithness, Scotland. Miner. Depos. 1989, 24, 117-123. [CrossRef]

48. Yu, Z.C.; Liu, L.; Qu, X.Y.; Yang, H.D.; Shao, M.L. Formation Temperature of Dawsonite from Qingshankou Formation in the Honggang Oilfield, Southern Songliao Basin. Acta Sedimentol. Sin. 2011, 29, 293-302.

49. Qu, X.Y.; Zhu, W.H.; Liu, L.; Dong, F.X. Petrology characteristics and the origin of dawsonite-bearing sandstone reservoir in southern Songliao Basin. Sci. Technol. Rev. 2015, 33, 13-19.

50. Ma, P.J.; Lin, C.Y.; Jens, J.R.; Jahren, J.; Dong, C.; Rena, L.H.; Hellevang, H. Cyclic zoning in authigenic saddle dolomite-ankerite; indications of a complex interplay between fault-rupturing and diagenetic alteration. Chem. Geol. 2021, 559, 119831. [CrossRef]

51. Li, Y.; Li, Q.L.; Yang, J.H. Tracing water-rock interaction in carbonate replacement deposits; a SIMS pyrite S-Pb isotope perspective from the Chinese Xinqiao System. Ore Geol. Rev. 2019, 107, 248-257. [CrossRef]

52. René, M. Anomalous rare earth element, yttrium and zirconium mobility associated with uranium mineralization. Terra Nova 2008, 20, 52-58. [CrossRef]

53. You, X.Y.; Jia, W.Q.; Xu, F.; Liu, Y. Mineralogical Characteristics of Ankerite and Mechanisms of Primary and Secondary Origins. Earth Sci. 2018, 43, 4046-4055.

54. Cheng, Y.H.; Wang, S.Y.; Zhang, T.F.; Teng, X.M.; Ao, C.; Jin, R.S.; Li, H.L. Regional sandstone-type uranium mineralization rooted in Oligo-Miocene tectonic inversion in the Songliao Basin, NE China. Gondwana Res. 2020, 88, 88-105. [CrossRef]

55. Wigley, M.; Kampman, N.; Dubacq, B.; Bickle, M. Fluid-mineral reactions and trace metal mobilization in an exhumed natural $\mathrm{CO}_{2}$ reservoir, Green River, Utah. Geology 2012, 40, 555-558. [CrossRef]

56. Zaccarini, F.; Stumpfl, E.; Garuti, G. Zirconolite and Zr-Th-U minerals in chromitites of the Finero Complex, Western Alps, Italy; evidence for carbonatite-type metasomatism in a subcontinental mantle plume. Can. Minerals. 2004, 42, 1825-1845. [CrossRef]

57. Mikysek, P.; Zikmund, T.; Dosbaba, M.; Brinek, A.; Slobodnik, M.; Adamovic, J.; Meszarosova, N.; Trojek, T.; Kaiser, J. Multi-scale visualization of uranium-rich domains dispersed in U-Zr mineralization of sandstone-type (Břevniště, Czech Republic). Ore Geol. Rev. 2021, 138, 104358. [CrossRef]

58. Qiu, L.F.; Li, X.D.; Liu, W.S.; Hu, B.Q.; Gao, L.; He, Z.B. Uranium Deposits of Erlian Basin (China): Role of Carbonaceous Debris Organic Matter and Hydrocarbon Fluids on Uranium Mineralization. Minerals 2021, 11, 532. [CrossRef] 